\title{
Ideologia neodarwinistă
}

\author{
Francisc Gafton ${ }^{1}$, Adina Chirilă ${ }^{2 *}$ \\ ${ }^{1}$ Facultatea de Litere, Universitatea „Alexandru Ioan Cuza”, Bd. Carol I 11, 700506 Iași, România \\ ${ }^{2}$ Facultatea de Litere, Istorie și Teologie, Universitatea de Vest, Bd. Vasile Pârvan 4, 300223 Timişoara, România
}

$\begin{array}{ll}\text { Despre articol } & \text { Rezumat } \\ \text { Istoric: } & \text { Credința dominantă încă în materie de evoluționism este că neodarwinismul } \\ \text { Primit } 9 \text { aprilie 2019 } & \text { reprezintă cea mai bună explicație evoluționistă, întrucit o conține pe cea dar- } \\ \text { Acceptat 15 aprilie 2019 } & \text { winiană, ameliorată prin ajustări și adaosuri furnizate de cercetarea științifică în } \\ \text { Publicat 7 mai 2019 } & \text { desfășurare, asiduă, obiectivă și străină de vreo ideologie. În fapt, pe parcursul } \\ & \text { istoriei sale, neodarwinismul a eșuat în menținerea unei linii de gîndire clare și } \\ \text { Cuvinte-cheie: } & \text { orientate de fapte. A devenit limpede că, urmîndu-i paradigma originară, nu } \\ \text { evoluționism } & \text { se putea rezolva problema evoluției; astfel că, pe parcursul ultimei jumătăți a } \\ \text { neodarwinism } & \text { secolului trecut, s-au manifestat încercări de ameliorare a neodarwinismului, } \\ \text { ideologie } & \text { fără succesele scontate. Eșecul se explică prin una din tarele curentului: res- } \\ \text { sinteză } & \text { pingerea categorică și arogantă a poziției lamarckiene în chestiunea evoluției. } \\ \text { lamarckism } & \text { Or, cercetările din deceniile recente și deducțiile logice pornite din observarea a } \\ & \text { ceea ce Natura produce impun revizuirea paradigmelor și anularea forței vreunei } \\ & \text { dogme. Cîștigul ar fi al științei și al cunoașterii umane. }\end{array}$

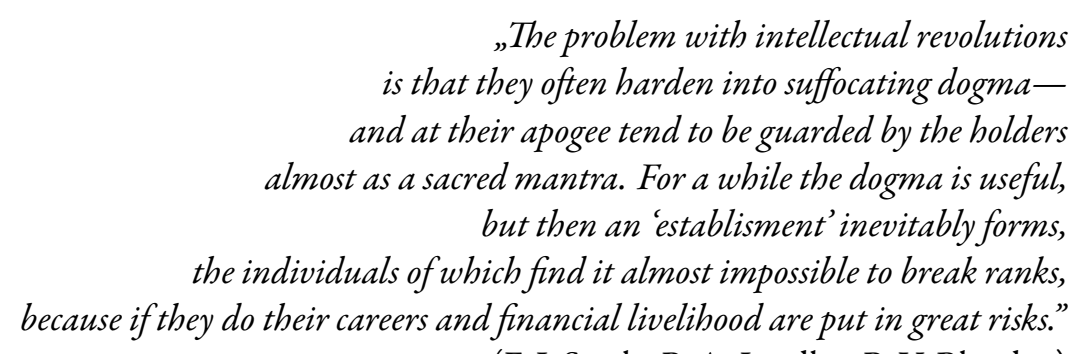

(E.J. Steele, R.A. Lindley, R.V. Blanden)

Preliminarii. Credința curentă în materie de evoluționism este că neodarwinismul reprezintă cea mai bună explicație ${ }^{1}$ evoluționistă, întrucît o conține pe cea darwiniană, ameliorată prin ajustări și adaosuri furnizate de cercetarea științifică în desfășurare. Totodată, se crede că poziția acestuia este pe bună dreptate dominantă, autoritatea sa decurgînd din științificitate, obiectivitate și din evitarea oricăror tentacule ideologice sau mize neștiințifice.

Apărut la o generație antropologică după Originea speciilor, neodarwinismul este astfel numit de către unicul elev al lui Darwin-Georges Romanes, cel care a păstrat linia magistrului său, construind un sistem lamarckiano-darwinian. El observa cu luciditate că neodarwinismul se poate închipui ca efect al unui proces dinamic, de continuă acomodare a darwinismului la noile descoperiri, însă concepția și realizarea sa îl fac să deformeze grav esența darwinismului, pe care, de fapt, îl neagă, desființează și înlocuiește.

\footnotetext{
*Adresă de corespondență: chiriladina@yahoo.com.
}

${ }^{1}$ „Se obicinuiește a se vorbi de «teoria evoluției», provocându-se înșelătoarea sugestie că această «teorie» n-ar fi decât una din nenumăratele «ipoteze» ce metoda științifică folosește ca unelte de cercetare și pe care le înlătură când, tocite, se pot înlocui cu altele mai bune. (...) Noțiunea de evoluție nu este nici ipoteză, nici teorie, este o constatare de fapt, este una din cele mai sigure și fundamentale dobândiri ale științei și constituie, împreună cu principiul conservării energiei, cea mai de preț comoară din zestrea, atât de greu agonisită, a omenirii de azi” (E. Racoviță, Evoluția şi problemele ei, 1929). 
Francisc Gafton, Adina Chirilă

La apariția sa, darwinismul irumpe cu forță, fotonii săi conceptuali străbătînd gîndirea occidentală, întrucîtva pregătită pentru înțelegerea noii perspective și explicații asupra evoluției viului ${ }^{2}$. Cu toate acestea, ne putem întreba: De ce, în cazurile neolamarckismului și neodarwinismului, diferă valoarea prefixoidului, care ar trebui să semnaleze doar un firesc aggiornamento? De ce în primul caz avem a face cu un proces prin care tînărul devine matur, iar în celălalt dăm peste un paricid care se înscăunează în locul părintelui, schimbînd canoanele și întreaga mentalitate socială, păstrînd doar aparențele date de nobilele veșminte? Apoi: Ce anume putea face ca în chiar timpul vieții lui Darwin, contemporanii săi să aducă modificări majore și profunde unor idei pe care oamenii de știință dar și publicul nespecializat însă instruit le înțelegeau, le acceptau și pe care învățaseră să le extindă la domeniul biologiei, la cel social și chiar la cel al Universului ? $?^{3}$ Pe de altă parte, ce anume îl putea determina pe Părintele explicației prin selecție naturală să accepte și, sporadic, să participe la complexul proces de rescriere mutilantă și modificatoare a propriei explicații?

Transformismul lamarckian. Cu jumătate de secol înainte de Originea speciilor, pe cînd Darwin abia se năștea, în 1809, Părintele evoluționismului modern, Lamarck, tocmai publica Philosophie zoologique, lucrare ce înglobează observația, experimentul și descrierea, evită speculațiile antropocentrice și integrează biologia în filozofia științei. În felul acesta se năștea biologia ca știință capabilă să devină un sistem generator de cercetări de încredere.

În vremea lui Lamarck deja se înțelegea că entitățile vii decurg din combinații aleatorii, cunosc variații accidentale-avîndu-și sursele în mediu, în organisme și în funcționarea interacțională a acestora一și pot deține capacităţi de supraviețuire și reproductive, în raport cu adaptabilitatea lor şi cu însușirea de a profita eficient de pe urma unor variații favorabile ${ }^{4}$. Se înțelegea și că o combinație poate fi compatibilă cu starea și dinamica unui mediu, dar poate suferi pînă la moarte într-altul, iar o schimbare drastică de mediu poate transforma o combinație compatibilă într-una defavorizată, și invers ${ }^{5}$.

Ideea de la care pleacă Lamarck este că, avînd la dispoziție materie, spațiu și timp, marele laborator care este Natura a acționat astfel încît, în virtutea proprietăţilor materiei și a cîtorva principii fundamentale, atomii au interacționat și s-au agregat, rezultatele dobîndind capacități autoorganizatorice și apoi autocatalitice. În felul acesta s-a ajuns de la atom la moleculă, iar de aici la celulă. Chipul acestui model se

\footnotetext{
${ }^{2}$ Inițial, Originea speciilor apare în 1250 de exemplare, care se vînd în ziua apariției, iar puțin peste o lună apare un nou tiraj-3000 de exemplare—, care se vinde rapid. Situația nu se schimbă mult în anii următori. Celelalte cărți ale lui Darwin de asemenea au avut parte de o primire bună.

„Abia la începutul secolului trecut începe adevărata încetățenire a evoluționismului în gândirea omenească, sub forma celei dintâi «teorii» cu caracter științific aplicată de către Lamarck originii viețuitoarelor, concepție folosită și de unii contemporani și urmași a săi. Pe terenul astfel preparat, cartea lui Darwin Originea speciilor, apărută în noiembrie 1859, vedem că pricinuiește o adevărată «revoluție» în spiritele naturaliștilor” (Racoviță, op. cit.).

${ }^{3}$ „Or, stelele sunt sori și s-a constatat că acești corpi cerești sunt toți în stadii diverse ale unei evoluții care îi mână cu neînvinsă fatalitate de la naștere, prin stadii tinere, apoi adulte, la bătrânețe și la moarte. Dar evoluția nu mână doar pe componenții lumilor cerești pe calea fără sfârșit a transformării (...). S-au descoperit nebuloase de toate vârstele, deci și aceste lumi nemărginite sunt mânate fără preget pe drumul neîntrerupt ce duce de la naștere până la moarte spre alte nașteri și alte morți (...). Planeta mărunțică, sluga plecată a soarelui, pe care ne rățoim noi, « regii creațiunii », este și ea supusă unei evoluții al cărui ritm poate să fie când mai încet, când mai grăbit, dar a cărei muncă fără odihnă a lăsat urme neșterse oricare ar fi depărtarea în trecut la care ajung să se avânte cercetările geologilor" (Racoviță,op. cit.).

${ }^{4}$ Desigur, adaptabil, adaptat, eficient, favorabil și alte asemenea atribute nu se asociază și înțeleg la modul absolut, ci doar în relație cu mediul, cu ereditatea și cu funcționalitatea.

„Adaptarea este tendința viețuitoarelor, niciodată realizată complect (sic; ș.urm.), de a ajunge la echilibrul compensator perfect între acțiunea mediului extern și reacțiunea consecutivă a organismului lor, tendință combinată cu aceea de a se sustrage complect de sub influența mediului extern, prin izolarea mediului intern și alcătuirea unui mediu artificial” (Racoviță, op. cit.).

5 „Lumea actuală a vietăților este rezultatul unei evoluții continue. Această evoluție este datorită direct influenței condițiilor de existență. Aceste condiții de existență variază continuu în timp, ele sunt diverse și în spațiu, deci niciodată și nicăieri identice. La acțiunea acestor variații corespund ca reacțiune variațiile viețuitoarelor, variații care se fixează prin ereditate și se răspândesc printre membrii aceluiași neam prin panmixie, adică încrucișare. (...) Rezultatul transformării este ori adaptarea directă la mediu, ori opunerea la influența mediului prin perfecționarea mediului intern și a mediului artificial. Nevoia adaptării continue atrage după sine o specializare din ce în ce mai strânsă, care poate să provoace stingerea spițelor, deoarece evoluția este
} 
manifestă la nivelul viului, ce apare dintr-o masă protoplasmatică nediferențiată care, datorită sensibilităţii și responsivității-și în virtutea tendințelor interne - poate răspunde proporțional, eficient şi adaptativ, atît cerințelor mediului în care își exersează existența, cît și propriilor nevoi. Această proprietate permite amorsarea proceselor existențiale și de dezvoltare, al căror exercițiu generează complexitate adaptativă și potențial evolutiv ${ }^{6}$.

Lamarck arată că fiecare astfel de rezultat—concordant și eficient în raport cu cerințele de mediu și cu nevoile și tendințele interne-aduce cu sine modificări de natură să determine întrucîtva structurile funcționale, fapt care va putea determina aspectul noilor rezultate-tot mai elaborate pe măsura desfășurării întregului exercițiu. Spirala coevolutivă astfel generată aduce cu sine atributul dinamicii interne și generează forme succesive de complexitate structural-funcțională și adaptativ-evolutivă. Prin urmare, concluzionează savantul francez, produsele Naturii sînt consecințe ale unor procese istorice succesive și gradate, supuse transformărilor adaptative și devenirii, în conformitate cu acțiunile legice ale mediului și organismelor.

În continuare el observă că, deși legile care guvernează întregul complex de procese au caracter universal și acțiune uniformă, efectele acțiunii factorilor de mediu sînt diferențiate-în cadrele concrete existențiale și de manifestare a mediului. Acest fapt generează forme felurite, a căror capacitate de devenireiarăși-se exprimă în chipuri și modalități diferențiate. Faptul că mediile existențiale concrete își exercită acțiunile particulare asupra unor corpuri individuale și colective-capabile de devenire și amprentate de respectivele medii-dezvoltă posibilitatea producerii de diferențieri structural-funcționale. Ca urmare, exercițiul orientat de mediul concret are printre efecte consolidarea structurilor funcționale întrebuințate, decăderea celor pasive sau neîntrebuințate, modificarea adaptativă a celor existente-totul în virtutea eficientizării structurilor și proceselor ${ }^{7}$.

În condiții neschimbătoare, trăsăturile respective se consolidează ca urmare a presiunilor de mediu în aceeași direcție și a satisfacerii tot mai specializate a acestora. Dacă rezultatele sînt benefice și comune ambelor sexe, atunci ele au șanse de a se transmite urmaşilor, care vor fi mai adecvat echipați, în relație cu solicitările reale dinspre condițiile concrete de viață către membrii speciei.

Lamarck arată că de aici decurg schimbări în modul de acțiune și apar noi deprinderi, instaurîndu-se noi echilibre; după care subliniază că singură acțiunea cerințelor de mediu nu este suficientă, răspunsul organismului fiind vital: reacției propriu-zise a organismului, prin care acesta se auto-ajustează nevoilor interne, îi urmează răspunsul adecvat și eficient, prin care acesta se acomodează cerințelor externe. Răspunsul este adaptativ și constituie expresia tendinței interne către adaptare, fiind parte a procesului de

ireversibilă. Transformarea spițelor se face ortogenetic sub influența imboldurilor îndreptate în același sens sau, în caz contrar, mai ales prin selecție naturală. (...) Acțiunea folosirii și nefolosirii organelor joacă un mare rol în transformarea speciilor, dar nu creează organe noi, ci adaptează la funcții noi organe vechi” (Racoviță, op. cit.).

${ }^{6}$ Ulterior, știința a confirmat observațiile lui Lamarck și le-a extins la nivelul proceselor care guvernează apariția și funcționarea Universului.

${ }^{7}$ „Una din cele mai mari descoperiri a întemeietorului evoluționismului în biologie, Lamarck, este ridicarea constatării obștești că exercițiul sporește puterea organelor la rangul de lege biologică generală. (...) Organele folosite, pe măsura și mărimea folosirii, se întăresc, se dezvoltă, se modifică și se adaptează din ce în ce mai mult (și ortogenetic, zicem) funcțiunii lor; organele nefolosite se reduc, se chircesc, variază (fluctuant și în direcții foarte diferite, zicem) și, în fine, dispar mai mult sau mai puțin desăvârșit, căci foarte de multe ori dăinuiesc sub formă de stârvuri informe, așa-numitele «organe rudimentare» (...). Această lege lamarckiană poartă numele de legea folosirii și nefolosirii și faptele concrete de la care a pornit nu sunt, dar nici nu pot fi contestate de nimenea. Lamarck însă a dat acestei legi o însemnătate și o extindere care este viu combătută de neodarwiniști. El pretindea că aceste modificări progresive se moștenesc și că, prin urmare, folosirea și nefolosirea sunt izvor de variațiuni care provoacă transformarea speciilor. Exemplele date de marele naturalist pentru a dovedi concepția au fost rău alese, încât nu a fost greu neodarwiniștilor ca să demonstreze lipsa lor de putere convingătoare; de aici, însă, sus-zișii adversari au conchis greșit că însăși legea este o greșeală. Școala modernă neolamarckiană a dovedit temeinicia legii prin însăși istoria bine deslușită a câtorva spițe, ca de pildă aceea a frumosului nostru rob calul, minunată istorie pe care v-am povestit-o în parte, dar cred îndestul ca să vă pot reaminti că evoluția piciorului multidigitat într-un picior unidigitat este un exemplu hotărâtor de rezultatul folosirii din ce în ce mai exclusive a degetului mijlociu (al III-lea), până ce a ajuns la sfârșit numai el întrebuințat și, din această cauză, singur enorm de mărit și întărit, precum și de rezultatul nefolosirii celorlalte degete, acum pipernicite ori dispărute.

Totuși, neodarwiniștii neagă tot; pentru ei, istoria piciorului calului este tot efectul selecțiunii naturale asupra unei variații 
complexificare a structurilor și funcțiilor ${ }^{8}$ - în anumite condiții rezultatele fiind stocate și trecute către urmași.

Lamarck arată astfel că: a) însăși viața constituie un rezultat al adaptării viului la condițiile realităţii (noi, schimbătoare, fluctuante etc.) și o formă de complexificare; b) procesele și schimbările adaptativedeterminate de capacitățile organismului dezvoltat în relație cu mediul și de cerințele de mediu—se pot achiziționa, modifica și acumula atît ontogenetic, cît și filogenetic.

În general, contemporanii lui Lamarck i-au înțeles explicația și i-au acceptat concepția. Rămîneau multe de lămurit, însă acesta este modul firesc și evolutiv în care avansează știința. Chiar astfel, unii dintre contemporanii săi au fost mai puțin receptivi la concepția savantului francez. Poate că la aceasta au contribuit mici variabile. Unele dintre cele arătate și susţinute de către Lamarck erau idei comune și mistuite de mentalul social—la a cărui configurare participaseră latent sau evident. Dar societatea momentului nu avea interesul focalizat în această direcție. Apoi, forma în care și-a prezentat Lamarck ideile deținea destule defecte de construcție, organizare și discurs. Acest fapt a făcut ca elementele cu care publicul era familiarizat să genereze impresia de redundanță, în vreme ce elementele de noutate-unele nefiind îndeajuns de distincte, altele avînd un nivel de complexitate greu de asimilat—nu dețineau destulă tranzitivitate ideatică. Acestor dificultăți curente li s-au adăugat îndărătnica și chiar acerebrala opoziție a cumplitului dușman al lui Lamarck, și anume, Cuvier. Acesta a reușit cu multă facilitate să-și împrăștie teoriile adesea eronate (diferite de cele susținute de către Lamarck) și a acționat cu neobosit talent în direcția discreditării lui Lamarck și a întregii sale ființe intelectuale.

Evoluționismul darwinian. Apărută de la sine și prin poligeneză, explicația evoluționistă s-a conturat, structurat, dezvoltat, adaptat și transformat treptat, ca urmare a confruntărilor avute cu elementele propriului obiect și cu cele ale universul socio-mental în care pătrundea. Exerciţiul direcționat a întărit-o, unele părți ale ei fiind succesiv reținute și transmise—cu sau fără modificări-, mereu adăugîndu-li-se noi achiziții, vremelnice sau durabile.

În momentul apariției lui Darwin, teoria celulară, cercetările asupra organelor omoloage și analoage, precum și asupra organogenezei-care demonstrează unitatea de structură a plantelor și animalelor, corelația dintre funcție şi structură, înrudirea dintre viețuitoare și dintre diferite grupe de organismeajunseseră la fundamentarea științifică. Alături de acestea și de alte achiziții din domeniile biologiei, geologiei, fizicii, chimiei și ale științelor gîndirii și sociale, observațiile și experimentele deosebit de minuțioase și de bine gîndite, practicate de către Darwin cu pedantă și dedicată minuțiozitate îl vor conduce la elaborarea unei explicații evoluționiste, care va avea în centru selecția naturală—concepută ca factor și mecanism.

În esență, orice explicație evoluționistă trebuie să lămurească procesul devenirii viului și procesul perpetuării sale. Înțelegînd că realitatea care cuprinde totul—adică mediul—nu este statică și imuabilă, iar factorii de mediu sînt variați, dinamici și interacționali, Darwin consideră variabilitatea ca regulă și proprietate a mediului și a produselor sale 9 . Variabilitatea mediului decurge din cea a factorilor de mediu și afectează (direct sau indirect) organismele. Variabilitatea organismelor decurge din relaţia acestora cu mediul și cu sine și afectează organismele și, posibil, mediul. În relaţie cu sine variabilitatea apare în consecința: a) întrebuințării sau neîntrebuințării organelor (cu rezultate transmisibile către urmași); b) stării de dezvoltare a organelor (care se pot corela structural și / sau funcțional) în relație cu organismul și a organismului cu mediul; și c) reproducerii prin încrucişare. Atunci cînd își are sursele în organism,

heterogenetice, adică săvârșindu-se în toate direcțiile; ei cred că dintr-un nămol de variații născute din voia întâmplării, dar toate ereditare, au dăinuit numai acele care duceau spre reducerea piciorului cu multe degete la piciorul unidigitat. Acele nenumărate variații cerute de teoria aceasta nu există decât în închipuirea neodarwinistă, căci nu se găsesc în muzeele paleontologice" (Racoviță, op. cit.).

${ }^{8}$ Chiar și interacțiunile intra- și interspecii constituie forme subtile de adaptare, care contribuie la menținerea echilibrului natural, orice tulburare și dezordine fiind doar aparente și concurînd în cele din urmă la ordinea generală. Între anumite limite, dezechilibrele exersează starea de echilibru, depăşirea limitelor îndemnînd la căutarea unei noi stări de echilibru.

${ }^{9}$ „Variația este legea fără excepții a universului; nu există înfăptuiri care să fie asemenea în toate ale lor. Identitatea desăvâr- 
variabilitatea se poate manifesta indiferent de mediu ${ }^{10}$. Rezultă că, întrucît mediul (intrinsec: presiune, temperatură, umiditate etc.; extrinsec: de la minerale la organice; relațiile dintre acestea și rezultantele lor $)^{11}$ este variabil, deopotrivă mediul și organismele sînt supuse modificărilor prin care le sînt afectate trăsăturile structural-funcționale și comportamentale, orice dezechilibru putînd induce dezechilibre, la toate nivelele ${ }^{12}$.

A doua regulă pe care o reține Darwin este ereditatea: părinții transmit progeniturilor atît trăsăturile pe care le dețin ca reprezentanți ai speciei (înnăscute), cît și trăsăturile achiziționate ca urmare a efectelor relației interacționale cu mediul (dobîndite). Ca urmare a intersectării cu acțiunea și efectele variabilității, ereditatea cunoaște abateri, mecanismele ei nefiind simple ${ }^{13}$.

Observînd că deși este supusă anumitor principii și urmează anumite legi fizico-chimice și biologice, acțiunea primilor doi factori nu poate asigura rezultatele evolutive care apar în realitate, apoi, avînd în vedere că înmulțirea naturală a viețuitoarelor (în progresie geometrică) ar duce la suprapopulație-soluția găsită de natură aflîndu-se în lupta pentru existență ${ }^{14}$ (intra- și interspecifică) —, Darwin a considerat că acțiunea variabilităţii și a eredității este ordonată de un factor selectiv, prin intermediul unui mecanism precis. În felul acesta a înțeles că: a) selecția naturală nu creează variații, dar le reține pe cele utile și le elimină pe cele dăunătoare-astfel ameliorînd organismele și populațiile—; și b) selecția naturală acționează la nivel de trăsătură, de parte, de individ, în acest fel mediat putînd afecta grupul, populația, specia

șită nu se pomenește decât în lumea imaginară a matematicienilor, iar formula ei fundamentală a = a este o absolută neexactitate" (Racoviță, op. cit.).

${ }^{10}$ Sub acest aspect, Darwin precizează cît se poate de limpede și de răspicat că totul are precedent cauzal, nimic nu este întîmplător, totul datorîndu-se (indirect) modalităților în care există și funcționează materia și legilor care o guvernează. De aceea, întrucît nivelul cunoașterii umane e teribil de scăzut, numim întîmplător tot ceea ce încă ne este necunoscut sau inexplicabil.

${ }^{11}$ E. Racoviță identifică factori naturali (fizici, chimici, geologici, meteorologici, nutritivi), biologici (efectele existenței celorlalte viețuitoare și elemente secundare din mediu) și interacționali (efectele interacțiunilor dintre elementele mediului vital).

Întrucît „vietățile sunt permeabile influenței mediului extern”, față de acesta organismele au dezvoltat prin reacție adaptativevolutivă un mediu intern, „ce toate fințele au agonisit cu mare trudă și cumplite suferințe, prin puzderia mileniilor, sub imboldul factorilor mediului extern și ca reacțiune mai mult sau mai puțin reușită contra influenței factorilor primari și biologici”, în felul acesta tinzînd să se elibereze de influența mediului extern și dobîndind „o libertate de acțiune din ce în ce mai complectă și o putere din ce în ce mai mare de a cuceri noi sălașe pentru neamurile sale”. În sfîrșit, viețuitoarele mai evoluate au dezvoltat și un mediu artificial. Acestea din urmă produc variații care decurg atît din funcționarea lor intrinsecă, cît și din existența și funcționarea lor în mediul extern. În primul rînd și, apoi, în cele din urmă, mediul dominant este cel extern. Spre deosebire de neodarwiniști care ,au ajuns să nege complect posibilitatea ca influența mediului extern să producă variațiuni importante și transmisibile posterităţii; iar faptul că nu au priceput rostul plin de hotărâtoare urmări al existenței unui mediu intern i-a adus la ispita de a pune aceste variațiuni nelegate direct de mediul extern pe seama zeului «Hazard» și a preacuvioasei «Întâmplări», idolatrie care se credea de mult ștearsă din năravurile naturaliștilor, E. Racoviță susține că: „Noi trebuie să zicem însă: toate variațiunile au ca origine variațiunile mediului extern, când direct prin acțiunea factorilor primari (fizici) și secundari (biologici), când indirect prin acțiunea factorilor mediilor intern și artificial, aceste două medii secundare nefiind ele însele decât produsul influenței mediului extern” (Racoviță, op. cit.).

12 „Evoluția viețuitoarelor se manifestă deci prin o adaptare de rigoare variabilă la mediul lor de trai; această adaptare este posibilă numai pentru că toate vietățile sunt variabile și fiindcă variațiile prielnice adaptării se trec ca moștenire descendenților. Din constatarea dependenței ființei de mediul în care gospodărește rezultă că explicarea imboldului la variație, că originea transformărilor trebuie căutate în însușirile acestui mediu (...). Adaptarea nu este niciodată perfectă, oricât de strâmtă ar fi ea. (...) La toate spițele se pot observa «dizarmonii adaptative», adică alcătuiri, năravuri și instincte care n-au niciun rost, sau naduc niciun folos, sau se arată mai puțin, mai mult sau chiar foarte vătămătoare. Dacă, cu toate acestea, spița viețuiește sau chiar înflorește, e că suma adaptărilor armonice întrece pe cea a dizarmoniilor adaptative cu o cantitate oarecare; când proporția se răstoarnă, spița tânjește și se stinge” (Racoviță,op. cit.).

${ }^{13}$ În chip firesc, indivizii mai bine dotați în relație cu mediul concret în care viețuiesc-adică adaptați sau ușor și eficient adaptabili la condițiile acestuia—au șanse mai mari de a supraviețui și de a se reproduce, transmițîndu-și materialul ereditar. În felul acesta urmașii au șanse de a căpăta genele care au asigurat adaptarea și supraviețuirea părinților. Dar perpetuarea acestora nu este asigurată pentru multă vreme, deoarece acțiunea variabilității poate modifica feluriți parametri de mediu sau biologici, astfel încît echilibrele potrivirilor să se modifice defavorabil pentru acea spiță.

${ }_{14}$ „A fost o greșeală că s-a întrebuințat pentru acest fenomen biologic cuvântul de «luptă »; ar trebui să se întrebuințeze exclusiv expresia de «concurență vitală » care oglindește mai bine adevărata ei însemnare (...). rezultatul ei de căpetenie este stabilirea echilibrului biologic" (Racoviță, op. cit.). 
sau chiar unități mai mari.

Datorită faptului că, în condiții de mediu modificate, fluctuante și solicitante în anumite direcții, inegalităţile dintre indivizi și populații pot deveni avantajoase sau dezavantajoase, se vădește că, de fapt, selecția naturală acționează ca un soi de sită care cerne organismele: cele ce răspund eficient cerințelor de mediu și nevoilor interne dăinuie (inclusiv prin progeniturile cărora le-au transmis trăsăturile înnăscute și dobîndite), celelalte pier (direct, din incapacitate reproductivă sau lăsînd urmași fără șanse de supraviețuire și/sau reproducere). Dacă solicitările mediului rămîn aceleași, acționînd constant în aceeași direcție, în acelaşi chip şi cu aceeași intensitate, trăsăturile dobîndite se pot transmite, fapt care se poate înregistra deopotrivă atunci cînd acestea constituie soluții eficiente la situații de criză majoră.

Deși pare un factor perturbator, variabilitatea provoacă mediul și viul la exerciţiu, fiind o solicitare care generează oportunități adaptative. La rîndul ei, ereditatea constituie factorul de stabilitate, care asigură transmiterea trăsăturilor de specie și echiparea cu soluțiile adecvate în vederea supraviețuirii. În sfîrșit, selecția este factorul și mecanismul ordonator, care asigură supraviețuirea și reproducerea viului, în condiții de adecvare la mediu. Fiecare dintre cei trei factori este rezultanta existenței și manifestării mediului (fizic, chimic, biologic, social, tehnologic, mental etc.), conține trăsăturile celorlalți-variabilitatea se perpetuează și este supusă selecției, ereditatea deține variabilitate și este supusă selecției, selecția cunoaște variabilitate și stabilitate—şi funcționează în condițiile mediului, deținînd variabilitate, constanță și selectivitate, fiind deopotrivă orientat (în condiţii neschimbătoare de mediu) și adaptativ (în condițiile unui mediu solicitant prin numărul, direcția, viteza etc. a schimbărilor).

Toate acestea arată că mediul nu este doar un cadru, ci și un factor, a cărui existență fizico-chimică și biologică generează factori și mecanisme de funcționare-în mediu și a produselor mediului. Iniţial produs al unui mediu, organismul biologic se adaptează la condițiile de stare și de dinamică a acestuia, astfel sporind potențialul de variabilitate, ereditate și selectivitate. Acest fapt poate afecta echilibrele, mișcările adaptative (ale elementelor mediului fizico-chimic, biologic etc.) nefiind decît forme de manifestare ale tendinţelor de reechilibrare, determinate de proprietățile fundamentale ale materiei și de efectele funcționării structurilor generate de aceasta. Mai departe, întrucît variabilitatea provoacă și generează schimbarea condițiilor, procesele adaptării trebuie să se petreacă în relație cu noua stare și cu noua dinamică, așadar

\footnotetext{
${ }^{15}$ Deși este limpede că mediul modelează organismele prin mijlocirea mecanismului selecției naturale, la rîndul lor, organismele care dăinuie și se înmulțesc pot influența condițiile de mediu - în primul rînd prin chiar simpla lor existență.

„Transformările datorite folosirii se îndreaptă în sensul imboldului care produce această folosire, adică în sens unic (...). Iată o vietate trăind în mediul ei vital băștinaș presupus normal, dar generalizat, adică un mediu care nu cere locuitorilor săi o prea strictă specializare. (...) imboldurile primite de la mediile ei vitale (interne, externe, artificiale) sunt cele care au hotărât adaptarea, adică acele ce se pot numi normale, prin urmare și organele lor vor fi în echilibru funcțional cu activitățile ce trebuie executate. Se schimbă însă unul sau toți factorii mediului extern (pădurea se transformă în câmpie, câmpia în mlaștină, mlaștina în lac etc.); imboldurile mediilor vor diferi, echilibrul funcțional al organelor se va transforma în dezechilibru, anumite organe, mai mult și altfel folosite, vor lua supremația și se vor modifica, pe când cele mai puțin sau deloc întrebuințate se vor chirci sau reduce complect. Un nou echilibru funcțional al organelor se va stabili, o nouă adaptare, mai mult sau mai puțin perfectă, va rezulta pentru vietate și așa mai departe. Astfel se va desfășura istoria și transformarea spiței, fără încetare, treptat, pas cu pas, când relativ mai repede, când mai încet, până când spița se va stinge prin o prea strâmtă specializare a structurii ei la medii care nu e posibil să rămână invariabile și care oricum trebuie să se schimbe de la o vreme destul de tare pentru a provoca pierirea vietăților ce nu mai sunt adaptabile" (Racoviță, op. cit.).

${ }^{16}$ Una dintre implicații este că la viteze mari adaptările pot duce la specializări ridicate—creînd organisme foarte eficiente în respectivele condiții, dar vulnerabile în unele diferite ori fluctuante.

„Tot ce e fenomen în univers este produsul unei evoluții, al unei transformări treptate care din ceea ce a fost a făcut ceea ce este azi și care va plămădi numai din cele de azi pe acele ce vor fi mâine; iar cele ce au fost odată nu vor mai răsări niciodată asemenea și vor fi vecinic diferite de cele de apoi (...). Legea ireversibilităţii este generalizarea constatărilor de fapt că un organ, odată ce s-a transformat, nu poate reveni niciodată la starea lui primitivă, că o alcătuire foarte specializată nu mai poate niciodată să revină la o stare foarte generalizată, că o spiță care a pierdut un organ nu poate să redobândească un organ identic. Ființa, odată pornită pe cărarea vieții, e sortită să meargă tot înainte, prin peisaje mereu schimbătoare, spre destine de mizerie sau glorie, spre lungi deveniri sau spre moarte grăbită, așa cum o va lăsa puterea celor moștenite și îngăduința mediilor vitale; dar pe aceeași bătătură nu se poate întoarce niciodată (...). Și ca să lămuresc bine miezul celor zise, întrebuințez următoarea parabolă simplistă: dintrun trunchi de copac poți stoleri orișice, să zicem că ai făcut o luntre și apoi din luntre o masă; din masă poți să faci anumite soiuri de scaune și din scaun ai destul lemn ca să faci o cutiuță. Din cutiuță te-ai apucat să faci un fluieraș și îți cânți de inimă
} 
supraviețuirea necesită obținerea unui nou echilibru' ${ }^{15}$. Se înțelege că deși mediul le cuprinde pe toate, întocmai precum un organism, el nu este atotdominator și imun la interacțiunile propriilor factori, simpla activitate funcțională a organismelor (parte a mediului în sensul său deplin) fiind în măsură să contribuie la variabilitatea mediului. Astfel de schimbări pot solicita iarăși mecanismele adaptative ale mediului şi ale viețuitoarelor, spre obținerea echilibrului-la nivelul întregului mediu-, care să configureze un mediu echilibrat și care să permită supraviețuirea și înmulțirea organismelor, în noua paradigmă de mediu. Parcursul acesta este spiralat și cumulativ, nimic nerevenind vreodată la stadii revolute ${ }^{16}$.

Explicația darwiniană seamănă pînă aproape de identitate cu cea lamarckiană, după cum remarca însuși Ch. Lyell, care considera că cea dintîi rezultă din modificarea celeilalte. Ambii înțeleg ponderea influenței mediului în modelarea propriilor componente (fizică, chimică, biologică etc.), precum și faptul că relațiile dintre factorii și componentele mediului generează dinamică și transformabilitate la nivelul tuturor componentelor şi al marelui întreg. Ambii consideră că întrebuințarea și neîntrebuințarea organelor deține o pondere importantă în modelarea organismelor, iar transmiterea trăsăturilor dobîndite este o realitate care contribuie la devenirea viului ${ }^{17}$. Deși Darwin mută accentele și produce o teorie proprie, cei doi sînt compatibili și la nivelul aparentelor diferențe. Cucerit de discursul lui Malthus ${ }^{18}$, Darwin se lasă convins de faptul evident al suprapopulației și vede în lupta pentru existență calea naturală de a păstra echilibrele, cu rezultatul supraviețuirii celui mai adaptat—dat natural care nu constituie un neadevăr. Lamarck nu a subliniat-o întrucît, în Natură, există deopotrivă concurență și colaborare, ale căror acțiuni și efecte se conjugă, nici una dintre fațete neputînd fi ridicată la rangul de principiu independent. Efectele resurselor incomensurabile pe care le deține materia și comportamentul obişnuit al materiei vii vădesc natura dialectică a relației dintre stabilitate și variabilitate, colaborare și concurență, fiecare factor luîndu-și forța din efectul de cuplu sinergic, iar nu din sine. Lamarck nu era interesat de aspectul a cărui saliență i-ar fi unicizat explicația făcînd-o memorabilă, ci de simpla cercetare care să înglobeze posibilitățile cognitive umane, spre înțelegerea realității.

În sfîrșit, conceptul care l-a făcut celebru pe Darwin, 'selecție naturală, este întrevăzut de către Lamarck, însă este ignorat întrucît, iarăşi, savantul francez nu era interesat de mecanisme-fie, importante, fie remarcabile, dar oricum limitate și fără acțiune universală—, ci de ceea ce le pune în mișcare, de trăsăturile de forță ale mediului.

În fapt, singurul lucru care îi deosebește profund pe cei doi zace în reliefarea-de către Lamarck-a tendinței spre complexitate a organismelor.

Retorica darwiniană. Explicaţia darwiniană este lipsită de generalitatea și de profunzimea celei lamarckiene, dar compensează prin detalierea nuanțată și acuta specificitate. Folosind cazuri concrete, constatabile sau verificabile, Darwin își masează forțele în zona în care există posibilitatea explicării convingătoare a proceselor și efectelor familiare (dar încă eronat, insuficient sau deloc lămurite). Într-o țesătură discursivă ce degajă puternica impresie a unui complex proces de cercetare dedicată, al cărei singur rost este cunoașterea întocmai a realității, Darwin desfăşoară la vedere un proces amplu de căutare a soluțiilor, cu evidențierea chiar a posibilelor contraargumente. Totodată, construcția dezbaterilor sale evită tentația digresiunilor reflexive, care să atragă către filozofare sau care să propună (ori doar să îndemne la) concluzii prea generale și care mînuiesc abstracții. Chiar și atunci cind naște impresia că doar se folosește de exemple concrete spre a urca pe treptele relatării către planul general, Darwin leagă fapte într-o construcție argumentativă bine chibzuită şi nu vizează explicit și preferențial obținerea unui raționament deductiv. El se ferește de orice posibilitate de părăsire a discursul vizual și referitor la concret, și încearcă să construiască o povestire lesne

albastră, când iată că vine potopul! Ei, fă-ți din fluier luntre dacă ai de unde! Așa-i că te-ai înecat și că ești șters de pe lumea viețuitoarelor la fel ca spițele cu pricina?” (Racoviță,op. cit.).

${ }^{17}$ De altfel, Darwin folosește din plin-în explicațiile din toate lucrările sale-influența mediului, întrebuințarea și neîntrebuințarea organelor și transmiterea trăsăturilor dobîndite, mai cu seamă în cazurile pe care selecția naturală nu reușea să le explice nicicum.

${ }^{18}$ Potențialul de suprapopulare și existența mai multor mecanisme de păstrare a echilibrului, unele selective sînt descrise de 
Francisc Gafton, Adina Chirilă

de urmărit, cu argumentație lămurită, presărată cu probe concludente, echilibrat întrețesute în canavaua materiei. El caută perpetuu dovezi revelatorii și solide—a căror validitate o încearcă sever一, spre a cuceri instantaneu, țelul fiind lămurirea cititorului și obținerea adeziunii acestuia.

Fără a cunoaște opera scrisă a lui Lamarck—dar avizat asupra conținutului ei și asupra eșecului pe care 1-au suferit deopotrivă Lamarck și explicația sa-, Darwin se va feri cu teribilă tenacitate de orice afirmație potențial neclară, insuficient argumentată și greu decelabilă pentru mentalul comun și de potențialul aflat acolo, sau care să apară în modalități greu admisibile în logica curentă ${ }^{19}$. De aceea, construcția discursului său abundă în elemente și modalități de retorică a prudenței și concilierii.

Fie bine cunoscuta sa teamă de orice formă de conflict (de la dezaprobare la blam), fie îndelungata observare a transformismului-cu efectul său frapant-l-a făcut pe Darwin să aleagă un titlu nu prea potrivit pentru prima sa scriere majoră. De fapt, el nu reușește nici măcar să definească riguros 'specia' (lucru nerezolvat nici astăzi, decît la nivelul uzului comun şi nespecializat; definiția cea mai potrivită rămîne cea a lui Lamarck, tocmai pentru că este nenuanțată ${ }^{20}$ ) și nici să arate originea speciilor ${ }^{21}$.

În adevăr, Darwin: a) constată că speciile nu sînt date și imuabile; b) arată modalitățile în care o specie deja existentă poate evolua generînd varietăți și, eventual, alte specii; c) propune și explică factori ai procesului evolutiv, apoi un mecanism care participă la evoluție și d) prezintă cîteva procese transformiste prin care trece viul. Urmînd un astfel de procedeu și vizînd un astfel de obiectiv persuasiv, Darwin reușește

către Lamarck în volumul I al Philosophie Zoologique, dar este conținută și la alți precursori ai lui Darwin.

${ }^{19} \mathrm{Nu}$ întîmplător a ezitat mult în fața gîndului de a-și publica lucrarea de căpătîi, căutînd continuu probe convingătoarenu doar din perspectiva sa—, multe dovezi importante fiind adăugate în ediţiile ulterioare și în Originea omului.

${ }^{20}$ Lamarck definește speciile ca fiind colecții de indivizi asemănători, care se perpetuează în aceleași condiții, atît timp cît mediul lor nu se schimbă într-atît încît să genereze variație în deprinderile, trăsăturile şi formele indivizilor. În felul acesta se evidențiază că speciile nu sînt date și imuabile, ci constituie doar o expresie tranzitorie a răspunsului-cu caracter istoricoprocesual-biologic la solicitări definite dinspre factorii de mediu și biologici. Răspunzînd corespunzător și adaptativ acestor factori, indivizii asemănători pot subzista și se perpetuează dăinuind ca atare atît timp cît condițiile de mediu nu le afectează starea de fapt în așa fel încît să apară modificări care să le afecteze integritatea structural-funcțională și capacitățile de a răspunde solicitărilor (interne și externe). În acest caz, specia se poate modifica în consecință, lent și fără salturi. Fără a se induce în eroare, Lamarck socotea că astfel de clasificări aparțin minții umane, Natura necreînd specii, genuri, familii, ordine, clase, ci doar indivizi înrudiți.

${ }^{21}$ „Prin faptul că nici variația, nici ereditatea nu sunt nemărginite, ba din contra, deoarece sunt foarte exact și de cele mai multe ori strâmt îngrădite, rezultă că vietățile sunt împărțite firesc în grupe de consângeni, în categorii de ființe care se trag toate din aceeaşi obârșie, care au moștenit aceeași zestre de însuşiri și care, cu toate că sunt fiecare diferite, nu pot trece în neasemănare peste o limită care constituie «caracterele lor specifice»; zic caractere specifice, căci rezervăm numele de specie (de soi) grupărilor astfel schițate” (Racoviță, op. cit.).

„Există atât de numeroase și de variate definiții ale noțiunii de specie, încât putem afirma că în realitate nu există niciuna, căci a defini înseamnă a izola o anume mărime cu o îngrăditură, dar să ai pretenția să definești o singură mărime izolând o mulțime de mărimi diferite e o treabă pe care o las mai bine pe seama altora. Eu susțin, în adevăr, că noțiunea de specie nu se poate defini dacă dăm termenului de «definire» tălmăcirea ce are în filozofie, în matematică şi alte logici. Cum să faci să intre în aceeași cutiuță a închipuirii omenești nenumărate puzderii de lucruri toate mai mult sau mai puțin, dar totdeauna diferite! După cum am văzut, nu există pe lume două vietăți identice; hei, cum s-ar putea că gruparea lor să deie naștere la categorii echivalente? Speciile astăzi stabilite de specialiști, de taxonomiști sau sistematicieni, cum le zice porecla, diferă complect prin valoarea caracterelor lor specifice, prin vechimea istoriei lor geologice, prin lărgimea limitei de variație, prin numărul coloniilor subspecifice ce au roit din ele, prin depărtarea înrudirii de speciile vecine și câte altele. Nu există două grupări mai mari de specii, cum sunt familiile, ordinele, clasele, în care speciile să fie unități de măsură perfect echivalente; eu susțin că chiar pentru gruparea primară s speciilor, pentru gen, se poate spune același lucru (...). Ce dovadă mai bună că specia este o realitate, dar o realitate relativă, cum sunt de altminteri și cum nici nu pot fi altfel toate realitățile naturale, căci dacă așa-zisele relații matematice sau logice pot fi absolute, e pentru că sunt artificiale, născocite anume ca să fie astfel” (Racoviță, op. cit.).

„Marele beteșug al noțiunii de specie e că a fost concepută de la început aplicându-se unui fenomen actual, adică unei înfăptuiri de azi care nu are nicio legătură cu trecutul (...). Nu există astfel de fenomene, căci toate derivă din fenomene anterioare și nici speciile n-au ieșit deodată din nimic. (...). Lipsește din acest concept o componentă capitală: trecutul speciei, originea ei, cunoașterea neamurilor din care se trage și a întâmplărilor vieții ei apuse. Speciile, ca și orice înfăptuiri lumești, nu sunt și nu pot fi creațiuni actuale, ci numai produse ale unei vechi și neîncetate înlănțuiri de acțiuni și reacțiuni, de cauze și efecte trecute devenite noi cauze de efecte actuale, acțiuni și reacțiuni cărora nu le cunoaștem începuturile; într-un cuvânt, speciile sunt fenomene istorice iar noțiunea de specie este o entitate morfologică (de formă și structură), geografică (de spațiu) și istorică (de timp). Ca s-o cercetăm complect trebuie s-o măsurăm în făptura componentelor, în spațiu și în timp, și numai atunci putem să 
să producă o explicație evoluționistă care sintetizează și valorifică multe dintre ideile de pînă la el, dar mai ales care interpretează, reliefează și restructurează acele idei, conjuncția particulară la care ajunge oferind o nouă perspectivă. Coerent închegată și trainic argumentată, teoria darwinistă nu are drept carențe decît cele inerente, cu care nivelul de cunoaștere ale epocii putea împovăra orice teorie din orice domeniu.

În momentul în care explicația sa a fost atacată, Darwin şi susţinătorii săi au căutat modalități de a răspunde constructiv obiecțiilor, nuanțînd explicațiile şi căutînd dovezi sprijinitoare. În momentul în care explicaţia sa a fost în pericol de a fi confundată cu lamarckismul, Darwin a făcut tot ceea ce i-a stat în putință spre a se diferenția de acesta, adesea infirmînd formal lucruri pe care nu doar le susținuse, dar pe care explicația sa se întemeia organic și fără de care ar fi devenit o ipoteză oarecare.

Pe de o parte, cele două explicații sînt modalități prin care se spune aproximativ același lucru, dar reliefîndu-se, o dată, originile, cadrul universal și mecanismele profunde (Lamarck), altă dată, situația aparentă și sesizabilă, dimpreună cu trăsăturile și mecanismele ei (Darwin). Pe de altă parte, cele două constituie un tot care conține atît esența, cît și fenomenul. Carențele fiecăreia dintre ele sînt omenești: profunzimile explorate de prima sînt atît de inaccesibile încît mecanismele concrete pe care mintea superficialei vietăți umane le cere ca dovezi îi rămîn neștiute, iar specificațiile pe care se străduie a doua să le dezvăluie sînt atît de nuanțate încît efortul de a explica puzderia de detalii și situații particulare depășește putințele omenești. Conflictul este fără ieșire deoarece, fără înțelegerea originii și a esențelor profunde, observarea stării aparențelor este lipsită de înțelegere, iar fără stările concretului, cunoașterea originii și esențelor rămîne lipsită de dovezi ${ }^{22}$.

Neodarwinismul. În chiar perioada în care explicaţia darwiniană tindea către stabilitate, încep să apară exagerările (atît la co-fondatorul care încearcă să nuanțeze și să clădească teoria în chipul în care a gîndit-o singur, cît și la adepți, care, în efortul de a (și-)o explica, o rafinează și-i încorporează noi idei). În esență, fascinat de factorul-mecanism evidențiat de către Darwin, neodarwinismul absolutizează rolul selecției naturale și respinge orice implicare a altui factor, practic îndepărtîndu-se de concepția darwiniană.

Întrucît comunitatea de orbită a două idei asemănătoare şi apropiate a constituit dintotdeauna un pericol—datorită posibilității de atragere a uneia în zona gravitațională a celeilalte-, iar soluția mereu declanşată instantaneu a fost fratricidul —în cazul de faţă, respingerea categorică a oricărei idei lamarckiene-, explicația darwiniană va fi respinsă prin ceea ce avea lamarckian în ea, adică prin întreaga ei esență. Pentru Darwin erau importante: influența directă și indirectă a mediului, întrebuințarea și neîntrebuințarea organelor și posibilitatea transmiterii trăsăturilor dobîndite. Pentru neodarwiniști primele două decad mult în importanță—căci sînt considerate vremelnice și limitate la o singură generație—, iar pentru cea de-a treia nu au urechi. În consecință, vor fi reținute adăugirile lui Darwin la Lamarck-dar în forme duse la extrem. Astfel, pentru Darwin, acțiunea selecției naturale reține sau dezvoltă deopotrivă trăsăturile rezultate din adaptarea directă și pe cele datorate întîmplării; acțiunea selecției naturale nu este foarte puternică, adeseori find implicați (și) alți factori; lupta pentru existență, cu consecința supraviețuirii celui mai adaptat, deține o pondere variabilă în ecuația generală, dar mereu acționează și alți factori. Pentru

ne lăudăm că o pricepem și că putem să ne folosim de ea pentru studiile comparate, adică pentru singurele cercetări ce ne pot duce la descoperiri de «legi», fără teamă de a cădea în greșeală. Și cum ai putea construi doctrina evoluției, ale cărei înfăptuiri și isprăvi strict actuale sunt nemărginit de mici față de cele făptuite într-un trecut nemăsurat de lung, dacă ar trebui să te servești numai de fenomene recente, despărțite artificial și samavolnic de trecutul lor firesc?” (Racoviță, op. cit.).

${ }^{22}$ „Lucrările lui Darwin au încetățenit în biologie transformismul, adică doctrina evoluției, și sub veșmânt darwinian aceste idei au pătruns în lumea mare. Starea actuală a vieții pe Pământ capătă prin această doctrină o firească explicație, și anume prin enorm de lunga istorie a neîntreruptelor înlănțuiri de spițe, dar ca lămurirea să fie complect satisfăcătoare trebuie să mai dezlegăm două probleme fundamentale; întâi originea variațiilor, fără de care adaptare și transformism nu poate să existe, și al doilea, persistența unora din aceste variații, adică ivirea de specii noi.

Geniul lui Lamarck a fost stăpânit de prima problemă, și cu drept cuvânt, căci este cea mai de căpetenie; soluțiile date de el sunt aşa-zișii factori lamarckieni: influența mediului de trai, moștenirea însușirilor dobândite, efectele folosirii și nefolosirii organelor.

Pe Darwin îl muncește dezlegarea celeilalte probleme, nelămurite de Lamarck. El admite factorii lamarckieni ca origine a variațiilor, dar pentru a lămuri cum se păstrează variațiile, adică cum se ivesc speciile noi, el pune în valoare o serie de factori: 
neodarwiniști acțiunea selecției naturale se exercită doar asupra trăsăturilor aleatorii; selecția naturală este unicul mecanism evolutiv, iar lupta pentru existență și supraviețuirea celui mai adaptat devin cruciale.

lupta pentru trai, alegerea firească, asemănarea ocrotitoare etc., factori grupați în limbajul naturaliștilor sub numele de factori darwinieni" (Racoviță, op. cit.).

23 „Știm ca Darwin admitea puterea factorilor lamarckieni, influența mediului extern, moștenirea caracterelor dobândite și efectele folosirii și nefolosirii; pentru el, deci, caracterele sexuale secundare sunt produsul acțiunii acestor factori combinați cu selecțiunea sexuală care, însă, crede el, joacă în această combinație de factori rolul de căpetenie. Dar neodarwiniștii nu admit alt factor decât selecțiunea sexuală, ceea ce i-a ademenit la născocirea a tot soiul de teorii, care mai de care mai curioase și mai metafizice” (Racoviță, op. cit.).

${ }^{24}$ „Noi, naturaliștii, nu închipuim subiectul cercetărilor noastre, noi îl constatăm pur și simplu” (Racoviță, op. cit.).

${ }^{25}$ „Ei pretind că variațiile nu se succed în sens unic, ci se manifestă în toate direcțiile, la întâmplare; pentru ei, evoluțiile întrun sens determinat, ca cele din exemplele citate, sunt rezultatul acțiunii selecției naturale, adică a alegerii și conservării, printre multe alte variații indiferente sau vătămătoare, numai a variațiilor favorabile. Ei înlocuiesc deci ortogeneza prin ortoselecție, adică alegerea unilaterală a variațiilor în anumit sens, variații născute la întâmplare odată cu tot soiul de alte variații. (...) Dar să ne înțelegem bine: Ortogeneza nu vrea să zică că evoluția se va îndeplini într-o spiță dată în sens unic, oricare ar fi influențele mediilor vitale, externe, interne și artificiale; a pretinde aceasta ar fi o greșeală mai mare decât aceea a neodarwiniștilor, ar fi o concepție de categorie creaționistă și curat metafizică. Sub termenul de ortogeneză trebuie să se înțeleagă pur și simplu transformarea unui organism sau a unui organ într-un singur sens sau, cu alte cuvinte, variația unilaterală. (...) Când mediile vitale se modifică într-o singură direcție sau când vietatea pribegește dintr-un mediu în altul, reacțiunea organismelor se va manifesta prin variațiuni ortogenetice; dacă aceste acțiuni ale mediului se opresc sau schimbă de sens, și variațiile menționate ale organismului se opresc și își schimbă direcția” (Racoviță, op. cit.).

${ }^{26}$ Weismann s-a ales cu același tratament pe care îl aplicase el însuși lui Darwin. Neodarwiniștii care i-au urmat au absolutizat unele spuse ale lui și au eludat altele, care, dacă ar fi fost reiterate și luate în considerare, ar fi schimbat, probabil, ceea ce este îndeobște recunoscut azi ca fiind cunoaștere în chestiunea evoluției. Astfel, teoria izolării și a purității germo-plasmei, a completei separări a germo-plasmei de somato-plasmă și a imposobilității ca vreo modificare a celei din urmă să afecteze plasma germinală au fost considerate aproape unanim un dat al viului. $\mathrm{Nu}$ a avut greutate cîtuși de puțin faptul că, reevaluîndu-și experimentele pe șoareci-Weismann și-a adunat datele tăind cozile a multor generații de șoareci și, notînd că, de fiecare dată, progeniturile unei generații mutilate etalau cozi normale, a dedus că o modificare la nivelul corpului nu produce o modificare la nivelul gameților-, experimentatorul însuși a putut concede că acestea nu fuseseră corect construite și că, prin urmare, nu validau convingerea în atotputernicia selecției. Ceea ce implica experimentul lui Wesmann era că amputarea cozii ar face imposibilă transmiterea înspre gameți a informației (şi comenzii) despre construirea unei cozi normale în generația următoare; or, eroarea experimentală constă—păstrînd cadrul de gîndire al lui Weismann—în aceea că tăierea se aplica unei cozi formate și întregi, deci care trimisese deja informația înspre germo-plasmă. În cele din urmă, Weissman a recunoscut că din mutilări nu se pot extrage concluzii referitoare le evoluția firească-lucru pe care mulți contemporani i-l repetaseră și a cărui înțelegere ar fi scutit ciopîrțirea sutelor de cobai.

De altfel, astfel de situații-în care ceea ce ajunge a se evidenția, în timp, ca gîndire nuanțată, evoluîndă a unui cercetător este deturnată și adusă de către posteritate la numitorul comun cel mai comod și mai convenabil—nu constituie excepții în știință; dimpotrivă. Privind de la înălțimea perspectivei diacronice, Lamarck observă ca organe deloc sau slab diferențiate, folosite cu predilecție în vederea satisfacerii anumitor nevoi au putut dobîndi structuri diferențiate, relația dintre forma și funcția lor devenind eficientă. Această adecvare a structurii la funcție a fost simplificată de către unul din adepții săi, E.G. de Saint-Hilaire, sub formula acroșantă și generalizată „funcția creează organul”, afirmație care nu-i aparține lui Lamarck, care de fapt arătase că funcția modelează organul, tocmai această continuă acomodare a două elemente conjugate fiind esența transformismului. Lucrul a fost corect înțeles de către H. Spencer, care arăta că modificările structurale decurg dintr-unele funcționale, fiind niște coadaptări-dar formula lui Saint-Hilaire și asocierea cu Lamarck au rămas neșterse.

„Din legătura dintre cauză și efect care există deci între funcțiune și organ, din faptul că s-a constatat existența unor sumedenii de organe foarte diferite la spițele actuale și, adaug eu, din lipsă de istorii amănunțite ale obârşiei neamurilor, care să ne permită cunoașterea originii reale a organelor, din toate acestea cauze, zic, s-a creat o «atmosferă » favorabilă ideii că funcțiunea, ca în vechiul concept creaționist, poate tot, chiar crea organe din nimic, poate chiar (culmea!) avea acțiune asupra a ceea ce nu există încă, căci dacă nu este acesta sensul, care să fie tălmăcirea formulei azi pretutindeni în favoare că funcțiunea creează organul?

Dar cum să-ți închipui funcțiune care să existe înaintea organului ei? Cum să crezi că vederea a creat ochiul când trebuie ochi ca să existe vedere? Cum să zici că respirația aeriană a creat plămânul dacă înainte de a fi plămân n-ar fi existat ale organe ocazional respiratoare în care să se exercite imboldul modificator al extragerii oxigenului din amestecuri gazoase și care să ofere suportul material pentru transformările ulterioare? (...). Transformarea vietăţilor nu se produce prin adăugiri şi zămislirii de organe noi pe lângă sau în locul celor vechi; ea rezultă din simpla modificare de organe și organite preexistente care împlineau funcții mai mult sau mai puțin diferite. Funcția nouă este deci împlinită de organe ce erau odinioară adaptate unei alte activităţi, iar aceste organe băștinașe au derivat ele înseși din organe preexistente corespunzând altor nevoi și așa mai departe. Funcția nu creează organul, cum greșit se zice azi; funcția readaptează organul preexistent. Da, vederea n-a creat ochiul, ci vederea născută în organe la început numai sensibile la variații de lumină, prin lenta transformare a acestora a făcut din aceste organe ce nu erau 
Lucrurile stau la fel în cazul selecției sexuale, și acolo Darwin indicînd un factor, iar nu factorul exclusiv ${ }^{23}$.

Wallace. Într-un sens, primul ne(o)darwinist a fost A.R. Wallace. Explicațiile evoluționiste ale lui Darwin și Wallace se aseamănă, dar numai în condițiile în care doi exploratori relativ contemporani observă o realitate comună și o concep într-un mod amprentat de același univers conceptual-mentalitar. Încă dinainte de a-l cunoaște pe Darwin, Wallace vorbește cu înfocare despre lupta pentru existență și despre supraviețuirea celui mai adaptat ca despre factorul unic al evoluției. Darwin reliefează faptul că lupta este atît de intensă încît șansa de supraviețuire a fiecărui individ poate gravita chiar și în jurul unei singure și ușoare variații, însă la Wallace varietățile sînt deja determinate de cauze pe care nu le discută, în cazul unei schimbări de mediu supraviețuind doar cele care se întîmplă să fie deja adaptate la respectiva schimbare. Aceasta este o breșă teribil de importantă și reflectă izbitor crevasa dintre opiniile și aplicațiile teoriilor celor doi. De fapt, în felul acesta, Wallace se manifestă (încă o dată) ca un oponent conștient, categoric și programatic al lui Lamarck, și ca un alter ego al lui Weismann.

Chiar și după apariția Originii speciilor, Wallace și-a păstrat în întregime vederile anterioare, rămînînd un susținător rigid, weismannian, al selecției naturale, pe care a continuat să o sublinieze în acest mod unic. În mod paradoxal, Wallace, weismannian și antilamarckian, credea, pe de o parte, în frenologie, iar de cealaltă, în ortogeneză și-în mod oarecum explicabil—credea în spiritism. Concepția sa generală nu vine însă din dobîndirea deductivă a unui adevăr demonstrabil, ci dintr-o zeloasă inducție ideologică ${ }^{24}$.

Selecționismul weismannian. Expresia plenară a concepției școlii neodarwiniene, cu toate exagerările în favoarea înnăscutului în detrimentul dobînditului, a aleatoriului în detrimentul acțiunii deterministe a mediului, cu schematizarea extremă a mersului evoluției și cu exacerbarea luptei pentru existență, apare la August Weismann.

Postulînd, în mod exclusivist, reducționist și absolut atotputernicia selecției naturale, Weismann subordonează selecției naturale, fără excepție, toate fenomenele biologice. El face din selecția naturală a variațiilor individuale, înnăscute și aleatorii factorul unic și mecanismul singular al evoluției-cu toate că însuși Darwin subliniase că deși selecția naturală este cel mai important factor, el nu este nicidecum uni$\operatorname{cul}^{25}$. Pentru Weismann selecția naturală este infailibilă deoarece-iarășii ${ }^{26}$ spre deosebire de DarwinWeismann și neodarwinișii extremiști considerau că toate trăsăturile specifice sînt utile, tot ceea ce operează selecția naturală fiind dotat cu utilitate ${ }^{27}$.

Explicaţia evoluționistă propusă de către Lamarck rămîne și astăzi cea mai coerentă dintre toate, dar ceea ce nu reușise acesta—și nu vor reuși nici cei de dinainte și de după Mendel, inclusiv Darwin—era să

ochi organele perfecționate ce numim ochi. Da, respirația aeriană n-a creat plămânii, ci respirația aeriană s-a născut într-un organ de origine ne respiratoare și apoi a transformat treptat acest organ «străin » în organ pentru respirație în mediu gazos. Așa stau lucrurile și așa se dau la iveală de câte ori se cercetează amănunțit istoria unei spițe omogene” (Racoviță, op. cit.).

„Aceste legi nu sunt concepte teoretice, ci rezultatele constatărilor concrete, constatări deduse din fapte cernute prin critică și seriate în generalizări legitime, ca și următoarea generalizare susținută de mine și care se leagă strâns de cele de sus: funcția nu creează organul, cum se obicinuiește a se zice și a se crede; funcția adaptează organe preexistente” (Racoviță, op. cit.).

Tot astfel, expresia survival of the fittest este creația lui H. Spencer, care o deduce din lectura Originii speciilor. De data aceasta, Darwin o preia și subliniază. Ceea ce s-a răspîndit în concepția obștească, în acest caz, este că ar fi vorba despre cel mai puternic, mai adaptat, mai potrivit, la modul absolut_fapt care ar constitui o imposibilitate pentru un organism biologic. În realitate, este vorba despre cel mai adaptat sau potrivit, exclusiv în relație cu condițiile contextuale concrete.

${ }^{27}$ Weismann consideră că selecția nu doar determină dezvoltarea unui organ, dar deopotrivă îl menține la un anumit nivel structural-funcțional. Atunci cînd se petrece suprimarea selecției, indivizii ce dețin organul respectiv și cei care nu-l dețin au şanse egale de a supraviețui și de a lăsa urmași. Întrucît cu toții participă în mod egal la reproducere, nivelul mediu scade astfel la fiecare generație, pînă cînd organul se atrofiază sau dispare complet. În felul acesta, Weismann își vădește fondul lamarckian, ignorînd o constatare a lui Darwin, care arătase că selecția naturală apare mai degrabă ca un regulator slab al adaptărilor existente, decît ca un factor care să le poată crea și dezvolta. Constatarea lui Darwin urmează observării faptului că utilitatea unei trăsături se arată a fi limitată la anumite grade ale dezvoltării sale: sub pragul utilității ea este instabilă, deasupra pragului, dezvoltarea ei poate merge prea departe, adesea depăşind utilitatea și chiar mergînd în răspărul ei.

Dar pentru Weismann, care își urmează neabătut gîndul, nu există nici structură, nici funcție pe care să nu ajungă a o explica presupunînd cutare utilitate, care i se pare a fi cea mai probabilă. Astfel de interpretări și de modalități de argumentare a orice, 
explice mecanismul transmiterii ${ }^{28}$. Dincolo de acest lucru însă, coerența ei amenința ideologia neodarwinistă și favoriza revigorarea lamarckismului.

De aceea, preluînd unele dintre ideile deja emise pînă la el, Weismann va construi treptat o teorie complexă al cărei rol era destinat să spulbere definitiv explicaţia lamarckiană. În esență, această teorie susține că organismele pluricelulare prezintă două tipuri de celule: unele care structurează organele (somatice), altele însărcinate cu transmiterea informației ereditare (germinale). Celulele germinale-care se autoreplică în nucleul fiecărei celule somatice-conțin materialul ce poartă informația pe a cărui bază se dezvoltă celulele somatice, material ce deține determinările necesare diferitelor tipuri de celule care vor îndeplini felurite funcții specifice. Parcurgînd etapele dezvoltării și intrînd treptat în funcțiune, celulele somatice dobîndesc tot mai multe atribute specifice, unele direct datorate determinărilor date de către celulele germinale, altele indirect, prin exercițiul tot mai specializat al funcției lor. Tot ceea ce se petrece cu celulele somatice ajunge să depindă tot mai mult de conjuncția dintre structura lor dezvoltată și efectele funcționării lor, fără a mai exercita efecte retroactive asupra materialului germinal. Totodată, variația individuală, înnăscută, aleatorie și avînd cauze interne este prezentă la nivelul celei mai mici componente celulare-imediat următoare moleculei-, care cunoaște lupta pentru existență. Aceste variații sînt diferențiate în funcție de tipul de celulă, cele germinale fiind ereditare și provocate de factori „necunoscuți”, cele somatice fiind determinate de acțiunea mediului extern și neereditare în vreun fel.

Se înțelege din cele de mai sus că celulele germinale și cele somatice prezintă capacități diferențiate, inalienabile și care nu pot fi transgresate. Adică procesele ereditare se pot petrece exclusiv prin intermediul și la nivelul celulelor germinale, acestea producînd atît celule somatice, cît și celule germinale, primele mărginite apoi la formarea componentei somatice a organismului, celelalte la asigurarea eredității. Din felul în care este imaginată reproducerea substanței germinale se înțelege că, virtual, substanța aceasta este nemuritoare, ea trecînd neschimbată de la o generație la alta. Separația dintre cele două tipuri de material este însă atît de fermă încît celulele germinale nu sînt afectate de ceea ce se petrece cu cele somatice, orice dezvoltare ori acumulare a acestora, din timpul exercițiului numit viață pierzîndu-se odată cu dispariția organismului individual. De aceea, informația genetică este transmisă numai de către celulele germinale, de la care trece către cele somatice, inversul constituind o imposibilitate: aceasta este aşa-numita barieră Weismann ${ }^{29}$.

Desigur, multe dintre cele susţinute de către Weismann nu erau eronate. De altfel, la acea vreme evoluționismul se exersase îndeajuns încît să înceapă a obține rezultate de încredere, să producă premise care să permită raţionamente și concluzii valide și conforme realității, să își creeze o metodologie și un instrumentar care să faciliteze cercetările de calitate. Cu toate că Weismann a fost un adevărat militant

vădit antropocentriste, marchează introducerea concepției finaliste acolo unde meritul ideii darwiniene fusese de a o înlocui explicația teleologică cu cea cauzală.

„Forțele fizico-chimice elementare, și mai ales cele mai simple cauze mecanice, sunt suficiente ca să ne explice modificările transformismului viețuitoarelor. Dar acest lucru nu-l putem constata decât cercetând foarte amănunțit și cu neînfrânată răbdare istoria spițelor omogene (Racoviță,op. cit.).

${ }^{28}$ Fuseseră emise felurite ipoteze, unele coerente și aparent confirmabile de realitate, unele foarte apropiate de concepția pe care o validează cercetarea științifică actuală, printre care teoria pangenelor, emisă de către Darwin și avînd esență categoric lamarckiană.

${ }^{29}$ Această concepție genocentrică a fost dezvoltată în secolul XX, o dată cu descoperirea structurii ADN-ului, de către J. Watson și Fr. Crick (1953). Referindu-se la direcția fluxului de informație genetică, Fr. Crick formulează așa numita dogmă centrală a biologiei, care susține că informația genetică se poate transfera de la acizii nucleici la acizi nucleici sau de la aceștia către proteine, dar nu și de la proteină la proteină sau de la proteină la acizi nucleici. Cu alte cuvinte, informația poate circula: a) de la ADN la ADN; b) de la ARN la ARN (prin replicare); c) de la ADN la ARN; d) de la ARN la ADN (prin sinteză); e) și f) de la ADN, respectiv ARN la proteine (prin sinteză), iar de aici la proteine, de asemenea, ARN-ul se poate replica. (După cum a mărturisit mai tîrziu, Fr. Crick nu cunoștea sensul termenului dogmă, pe care l-a folosit doar pentru caracterul său acroșant. Ceea ce voise a semnifica era 'ipoteză.)

La rîndul său, coautorul descoperirii structurii de ADN, J. Watson a emis o formulare ușor diferită—dar memorabilă—: informația din $\mathrm{ADN}$ poate trece în ARN, iar de aici către proteine, însă de la proteine nu poate parcurge calea inversă. Neodarwiniștii neagă realitatea acestei variante a „dogmei centrale” deoarece permite explicația lamarckiană. Mai mult, cercetările recente au arătat că există posibilitatea ca proteinele să poată transmite informație către alte proteine (prin replicare), precum și 
anti-lamarckian, care s-a servit de citeva idei ale lui Darwin, multe dintre cele pe care le-a susținut și-cu deosebire—substratul profund și nevăzut al gîndirii sale era de esență lamarckiană, pe acesta altoindu-se ideile referitoare la lupta pentru existență și la selecție naturală.

Rezultanta construcției sale conștient edificată și orientată este însă tezistă, determinată ideologic și de aceea eronată ${ }^{30}$.

Astfel, teoria selecției germinale a lui Weismann, apare ca efect al înțelegerii de către acesta a limitelor selecției naturale, a neatotputerniciei ei, a faptului că este slabă. Ea nu poate explica apariția variațiilor folositoare și dezvoltarea celor neutre, și nici nu poate iniţia noi linii de dezvoltare și de descendență. De aceea, încercînd să folosească structura somatică a darwinismului pentru a da aură propriei explicații, construcțiile mentale weismanniene (antilamarckiene și nedarwiniste) încep ca un șir de speculații care se succed înlocuindu-se-întrețesute cu rezultate ale unor experimente în domeniile chimiei și biologiei-, ajung să nege și să distrugă darwinismul lui Darwin, în cele din urmă generînd o formă de lamarckism și exersînd sistemul de gîndire neolamarckian. Într-un sens, în ciuda a ceea ce se petrece la nivel declarativ, Weismann a sprijinit lamarckismul și a desființat doar o componentă a sa: darwinismul ${ }^{31}$.

Plecînd de la miza centrală: combaterea posibilității de transmitere a trăsăturilor dobîndite, Weismann ajunge la postularea imortalităţii substanței germinale, adică neagă transmiterea selectivă a unui material ameliorat ca urmare a exercițiului adaptativ-evolutiv și afirmă imuabilitatea și nemurirea matera-

către ARN și ADN (prin sinteză). În acest caz—care acumulează dovezi tot mai numeroase și mai concludente-, neodarwiniștii recurg la mijlocul folosit de ei în situațiile grave sau fără ieșire, redefinind „conciliant” termenii, mutînd limitele și dînd impresia că își mențin poziția intactă. În felul acesta, pe domeniul eredității a fost creată zona epigeneticii, pentru situațiile în care manifestările ereditare care apar, deși efective, nu alterează secvențele de nucleotide.

Acest tip de sofistică nuanțează în chip nefiresc notele de conținut sau le ambiguizează, îngustînd sfera definiției. Născocirea de noi note și nuanțe, distribuirea entităților către alte sfere sînt mai ușor de operat, nu dau adversarului prilejul unei demonstrații neîntrerupte, dar stimulează o contrademonstrație—la fel de sofistică_prin care se arată că ceea ce doar pare a aparține aceleiași sfere, de fapt nu ține de o alta, care nu constituie obiectul discuției. În felul acesta, adversarul ajunge fi forțat să se autocenzureze sever și la tot pasul, ceea ce-i fărîmițează periculos de mult activitatea și pemite o victorie nominală. (Unul dintre efectele adverse și de ricoșeu—de care un evoluționist ar trebui să fie instinctiv avizat și să nu le poată ignora—a fost că prin astfel de procedee cadrele neodarwinismului s-au rigidizat, încît tovarășii care s-au alăturat ulterior nu au mai avut libertăți reale de gîndire și de acțiune.)

În fapt, ereditatea nu se reduce la dimensiunea genetică, iar ereditatea genetică nu constituie tipul de ereditate „prin excelență”-altele fiind „slabe”-, cu atît mai mult cu cît ereditatea cunoaște forme de existență, de dezvoltare și de evoluție ... ereditare și neereditare.

30 „Numai modificările ivite în germen sunt ereditare, căci ovulul fecundat de spermatozoid formează exclusiv progenitura vietăților, e singura legătură între părinți și copii, e nemuritor, căci se transmite neîntrerupt din tată în fiu atât timp cât dăinuiește o spiță. Germenul este zestrea ereditară a speciei; soma, proprietatea pieritoare a indivizilor, o simplă găoace de apărare și o credincioasă slugă hrănitoare a acestui germen pe care, ferindu-l de contact direct cu mediul vital, îi suprimă prin aceasta și orice directive în variații, care se pot deci manifesta în toate direcțiile. Adaptările, adică satisfacerea cerințelor mediului vital prin variații corespunzătoare, le lasă Weismann pe seama selecțiilor naturale, exagerându-le puterea reală. Independența germenului în soma este pârghia doctrinei weismanniste, dar și capitala ei greșeală. Creând două entități metafizice, Weismann a luat o cale care nu putea duce decât la sofism.

Distincția între germen și soma este în realitate de aceeași valoare ca distincția între două țesuturi diferite oarecare, mușchi și oase, de pildă (...).

Desigur, moștenirea părinților nu se poate transmite copiilor în cazul reproducției sexuate decât prin microscopica picătură vie ce constituie ovulul fecundat, dar acest ou este format din aceleași substanțe ca soma, este hrănit și crescut de soma și nu este posibil ca influențele suferite de soma să nu i se transmită, mai mult sau mai puțin intens și mai de grabă ori mai târziu. Că sunt transformări somatice care nu pătrund în germen cu una cu două e fapt, dar că sunt de acele care pătrund până la el, cu vremea, e alt fapt. Că la spițele cu mediu intern bine izolat, influența factorilor externi tinde a se micșora și că aceea a celor interni a spori se înțelege de la sine; faptul explică de ce, pentru a înțelege nemoștenirea multor influențe externe și apariția multor variații de origine aparent misterioasă nu e nevoie de conceptele metafizice ale lui Weismann.

Din momentul ce te decizi să sustragi germenul influenței mediilor vitale, unde să-i găsești imboldul pentru variație? În lumea realității nu se găsește altul. Weismann a căutat acest imbold în închipuirea sa cu adevărat bogată și ingenioasă, construind germenului o structură măiastră, minunat de logică, dar în care «particulele» reprezentative de «caractere», adică concepte pur metafizice, joacă rolul principal” (Racoviță, op. cit.).

${ }^{31}$ „Fac parte din categoria de naturaliști ce au ajuns la liniștea sufletească izvorâtă din convingerea că își îndrumă gândul și munca pe calea ce duce spre priceperea fenomenului, adică spre adevărul accesibil minții omenești. Dar nu toți biologii se 
lului primitiv, mereu capabil să genereze forme tot mai performante, dar incapabil de orice evoluție. Alte teme nu sînt decît adiacente, arme, fronturi și strategii auxiliare, construcția neodarwinistă nefiind una reală, ci doar o mașină de demontat construcția lamarckian-darwiniană.

Semnificativ și relevant, la urma urmelor, este că acela care toată viața a stat în tensiunea dintre concepția religioasă și cea științifică, acela despre care se spunea că a învins definitiv lamarckismul a început ca lamarckian „ortodox”, după care, înfocat precum un adevărat apostat neofit, s-a îndepărtat căutînd o explicație proprie, apoi a trecut prin tabăra darwiniană pe care a pustiit-o de miezul ei viu, după care și-a croit o formă proprie de lamarckism, aflată într-un punct al singularității. Cu toate că, în realitate, datorită lui Weismann, gîndirea din biologie, din unele zone ale filozofiei și din alte ramuri ale științelor gîndirii și ale celor sociale a rătăcit suferindă peste un secol, părintele eșecului neodarwinist a rămas inexplicabil de respectat împreună cu urmaşii săi din secolul XX.

Sofistica weismanniană. Atunci cînd se opune lui Lamarck și îl corectează distorsionant pe Darwin, Weismann nu se întemeiază pe cercetări anterioare sau pe unele proprii de încredere, ci este statornic în credința că lucrurile nu trebuie să fie așa cum sînt prezentate de cei doi. De aceea, experimentele pe care le face sînt astfel concepute încît să infirme concepția lamarckiană și masiva componentă lamarckiană a explicației darwiniene. Este posibil ca Weismann să fi înțeles întocmai ceea ce susținuseră cei doi și să nu fi interpretat unilateral unele aspecte. Este sigur că, în consecința unui raționament grevat ideologic și sinuos, el încerca să prevină posibile consecințe pe care tot el le punea pe seama posibilelor interpretări ale altora, la explicația lamarckian-darwiniană ${ }^{32}$.

Pentru cine analizează discursul sofistic, tehnica lui Weismann este fascinantă, ea fiind deprinsă și practicată din plin de către neodarwiniștii contemporani și următori ${ }^{33}$.

În primul rînd, adversarilor li se cer dovezi minuțioase în sprijinul fiecărei secvențe asertive, dar și pentru orice contraargument faţă de cele susținute-fără dovezi-de către Weismann. Pe măsură ce adversarii aduc dovezi, acestea sînt respinse, nu prin contra-dovezi sau prin expunerea slăbiciunii ori a lipsei lor de potrivire cu situația, ci printr-un discurs bagatelizant și evaziv, construit din sofisme discursive de tot felul (adesea de argument, dar, cele mai multe ori, de tehnică și de condiții ale argumentării), toate dominate cumva de ignoratio elenchi. În felul acesta, orice dovadă a transmiterii trăsăturilor dobîndite este spulberată fie afirmîndu-se că experimentul nu a fost corect executat, fie arătîndu-se că ceea ce se petrecuse era rezultatul selecției naturale, fie redefinind continuu trăsăturile dobîndite și ereditatea! Toate experimentele sfîrșitului de secol XIX și ale începutului de secol XX ${ }^{34}$ — prin care se încearcă simpla înțelegere a eredității și a posibilității de transmitere a trăsăturilor dobîndite—sînt privite de către Weismann și adepții neodarwinismului ca neserioase, lipsite de credibilitate, trucate, în cel mai bun caz eronate; oricum, de respins $^{35}$. În acest context nu poate mira faptul că, în construcțiile sale teoretice și mentale, lupta pentru

bucură de această stare sufletească, căci s-au ivit câteva «cataclisme teoretice» care au părut că zguduie din temelie doctrina transformistă astfel cum o construiește Lamarck, Darwin și o parte din urmașii lor” (...). „Convingerea mea este că neodarwiniștii au să fie la urma urmei exterminați, cum au fost făcuți praf creaționiștii” (Racoviță, op. cit.).

${ }^{32} \mathrm{Ce}$-i drept, foarte multe teorii emise de-a lungul istoriei umanității au fost judecate înainte de a fi înțelese întocmaimai ales în funcție de implicațiile pe care le induceau mințile prevenitoare ale criticilor. Dar tocmai acestor le cazne supunea Weismann explicația darwinistă.

${ }^{33}$ „Critica lui Weismann, strălucită prin calitățile stilului, prin energia convingerii, prin subtilitatea dialecticii, a impresionat adânc pe acei biologi care nu aveau experiență personală în studiul istoriei spițelor, adică pe marea majoritate a biologilor, și astfel s-a iscat o luptă aprigă, care durează încă, între neolamarckiști și neodarwiniști, deoarece Darwin admitea rolul transformist al factorilor lamarckieni, pe când Weismann și școala sa îl neagă formal. (...) Nu am vreme să vă expun această teorie explicativă a lui Weismann care a furat mințile multor biologi la sfârșitul secolului trecut, dar nici nu face s-o cunoască cineva (...). Din tot weismannismul nu va rămânea decât partea negativă, incisiva critică cu care a curățit câmpul transformismului de multe buruieni, de multe observații rău făcute sau rău tălmăcite. Va mai dăinui poate încă multă, vreme în mintea discipolilor, negarea îndărătnică a factorilor lamarckieni, dar toată partea doctrinară pozitivă care trebuia să explice transformismul e deja prăbușită cu desăvârșire” (Racoviță, op. cit.).

${ }^{34}$ A se vedea V.L. Kellogg, Darwinismul astăzi, Iași, 2017, și Y. Delage, M. Goldsmith, Teoriile evoluției, Iași, 2015.

${ }^{35}$ Pentru toate situațiile, explicația weismanniană era aproape invariabilă: a) trăsăturile organismelor decurg din manifesta- 
existență și selecția nu sînt înțelese ca factori, mecanisme sau procese, ci devin abstracții metafizice, un soi de Deus ex machina.

Modalitatea intransigentă, exclusivistă pînă la dispreț cu care Weismann și neodarwiniștii s-au purtat cu cei care le aduceau explicațiile cerute și chiar cu explicaţiile însele arată că, pe de o parte, acestea nu erau de tip științific, ci ideologic, adică rostul explicațiilor weismanniene nu era de a-i face pe ceilalți să înțeleagă cum stau lucrurile în realitate, ci de a-i atrage la concepția lor și de a consolida credința adepților, de cealaltă, explicațiile cerute de la alții erau adevărate acte de respingere de plano a concepției acelora—nu un mesaj către dialog, ci unul de descurajare.

În contextul în care știința este un continuu proces istoric, constituit prin raţionamente și adevăruri negative, cu firave confirmări, ceea ce uimește la Weismann și la neodarwiniștii din toate vremurile este fermitatea și siguranța neștirbită, certitudinea inebranlabilă cu privire la propriile ,adevăruri”- trăsături caracteristice mai degrabă celui mînat de flacăra ideologiei decît celui călăuzit de palida lumină a științei. Încă și mai descumpănitoare este marea disponibilitate de a elimina atît de categoric date care, ca oricare altele, ar putea servi științei-mai ales atît timp cît nu li s-a demonstrat caracterul invalid și aberant—și mai ales în contextul în care identice respingeri anterioare fuseseră ulterior invalidate de cercetarea științifică.

Știind că analiza critică a ideilor și soluțiilor este parte integrantă a științei și procesului de aflare a stării realității, fiind indispensabilă, chipul în care Weismann și neodarwiniștii au respins orice alte soluții vădesc oricui partizanatul lor. S-ar putea spune că, așa cum apostolul Paul a stabilit bazele indestructibile ale discursului argumentativ creștin, tot astfel Weismann a fixat procedeele retorico-sofistice de respingere a oricărui argument care nu concordă pe deplin cu dogma pe care a întemeiat-o. În consecință, opoziția şi disprețul vor deveni blam coercitiv şi marginalizare eliminatorie, neolamarckiștii sau oricine putea fi bănuit de a purta o umbră părelnică lamarckism fiind surghiunit în zonele inerte ale comunităţii științifice, însuși cuvîntul Lamarck atrăgînd automat și visceral atribute dintre ele mai izolante, de la cele laice, precum neștiințific și inepție, la cel suprem ideologic: erezie.

Dar dincolo de neajunsurile care întovărășesc prigoana ideilor (lamarckiene)—care încă dăinuie în zilele noastre一, reacțiile corpului de lamarckieni și darwiniști au produs o adaptare. Rîvna astuțioasă a lui Weismann de a elimina orice urmă de lamarckism, golind întreaga substanţă vitală a darwinismului şi modificind profund conceptul reținut ca fundamental, 'selecție naturală, și atitudinea de respingere wiesmanniană a orice era sau putea fi diferit de cele susținute de el i-au determinat pe cercetători să caute dovezi riguroase cu ajutorul observației și mai ales al experimentului, să fie mai severi în avansarea și formularea de concluzii, ipoteze și teorii.

Funcționalismul baldwinian. Tulburările create de doctrina weismanniană au generat o reacție naturală în asemenea situații. În vremuri în care doar cîțiva temerari mai au tăria de a se declara (neo)lamarckieni, una dintre soluțiile de subzistență ale organismului biologic sau ale gîndului proscris este identificarea elementului prohibit, separarea de acesta și construirea unei forme care să poarte esența gîndului, modificată pînă la limita păstrării sale și a acceptării de către ceilalți. Deși-în mod cu totul semnificativ și neîntîmplător—gînditorii de esență lamarckiană au îmbrățișat darwinismul autentic, datorită faptului că aceasta nu constituia o sinteză a explicației lamarckiene la care să se adauge inovațiile Darwin, ei nu puteau abandona concepția savantului francez, înlocuind-o cu cea a lui Darwin. Fără a se angaja în colaborări programatice, încorsetate de vreo ideologie — cum vor proceda neodarwiniștii secolului XX-gînditorii lamackieni ai sfîrșitului de secol XIX (precum J.M. Baldwin, H.F. Osborn, Th. Eimer, E.D. Cope și alții)

rea variațiilor aleatorii, asupra acestora acționînd selecția naturală - care este atotputernică și infailibilă; b) aparenta transmitere către urmași a respectivelor trăsături este simpla consecință directă a succesului reproductiv al organismelor care le poartă; c) în condițiile în care acele trăsături devin dăunătoare, dezavantajînd organismul, șansele de supraviețuire și reproductive ale organismului purtător scad proporțional, și implicit acele trăsături; d) locul nu rămîne liber întrucît trăsături utile în noul mediu vor apărea-tot întîmplător-la nivelul altui organism.

De asemenea, ridicînd la rang de dogmă ipoteza utilității oricărei adaptări selectate sau supralicitata selecție sexuală (explicație mai degrabă hermeneutică decît provenită din și confirmată de realitate) weismannienii duc la extrem procedeul prin care cer adversarilor dovezi indubitabile, în timp ce pentru propriile afirmații din materia de mai sus singura explicație este că, neavînd 
vor încerca sinteze și explicații independente, fiecare dintre acestea conținînd elemente de valoare, fiecare avîndu-și propriile carențe. Datorită chipului în care îmbină elementele și mai ales datorită posibilității de succes pe care o creează $\breve{3}^{36}$, explicația pe care o vom aminti aici va fi cea a lui Baldwin.

Ca psiholog evoluționist, cercetătorul american are prilejul de a face unele observații-precum rolul și importanța exercițiului, care funcționează în tensiunea dintre încercare / eroare și generează rezultate sub forma imitației creative-care îl vor ajuta să înțeleagă realitatea dintr-o perspectivă benefic amplificată. Baldwin acceptă că organismele prezintă variații proprii și nedeterminate de mediu (înnăscute). Totodată susține că organismele pot dobîndi structuri și funcții ca urmare a adaptării lor succesive la condițiile variabile ale mediilor concrete în care există și funcționează. Fiind de acord cu influența ambelor tipuri de variații, el arată că, în condițiile în care se întîmplă ca acestea (variația înnăscută și adaptarea) să concure la dezvoltarea aceleiaşi trăsături utile, organismul este avantajat în mediul respectiv; de asemenea, în cazul în care cele două trăsături sînt corelate. În felul acesta, procesul de transmitere a trăsăturii înnăscute va antrena transmiterea trăsăturii dobîndite. Viețuirea într-un mediu cu solicitări constant direcționate întro direcție poate face ca după un număr de generații, adaptarea inițial ontogenetică să fie înglobată și să capete caracter filogenetic. Ulterior, modificările dobîndite pot ajunge să influențeze variațiile înnăscute.

$\mathrm{O}$ astfel de selecție, în cadrul căreia variabilitatea naturală se conjugă cu modificarea generată de solicitările mediului, este numită de către Baldwin organică sau funcţională. În felul acesta se arată că, pe de o parte, factorii genetici își urmează propriile căi de manifestare, acțiunile lor ducînd la efecte consecvente, iar de cealaltă, factorii de mediu își exercită influențele în chip propriu. Rezultanta acestei conjuncții generează posibilitatea ca factorii epigenetici să îi modeleze pe cei genetici, în chipul presiunilor selective. Prin urmare, nu doar genomul își determină produsele, dar este posibil ca pe calea comportamentală, în condiții de intensitate și de repetabilitate a exercițiului şi de constantă presiune dinspre un mediu stabil, genomul să poată fi modelat, întărindu-se sau debilitîndu-se trăsături genetice.

Intențiile bune și drumul spre iad. Începînd cu 1917 și pînă către mijlocul secolului XX, un grup relativ eterogen de cercetători (printre care R. Fischer, J. Huxley, Th. Dobzhansky, R. Haldane, G.L. Stebbins, E. Mayr, G.G. Simpson, G. de Beer, S. Wright) —ale căror calități intelectuale și morale (excepționale, în destule cazuri) nu pot fi negate-a pus în act o încercare de a promova doctrina evoluționistă, sub numele Sinteza Evoluționistă Modernă (SEM). Era rezultatul unui efort conștient și entuziast, care declara că unifică teoria mendeliană asupra eredității și principiile neodarwiniste cu paleontologia, genetica, ecologia etc., adică cu progresele pe care le făcuse cunoașterea în domeniu, după Darwin (dar care nu ajunseseră încă să cuprindă și chimia și comportamentul genei). Cu toate acestea, acțiunile direcționate ale diferiților aderenți la această idee arată clar că întregul efort era orientat către salvarea nucleului epurat și simplificat al weismannismului-anume, teoria mutație-selecție-cu încercarea tenace de a-i evita „tarele” lamarckiene.

Teoria mutație-selecție dedusă din eforturile lui Weismann poate fi rezumată în cinci postulate: 1) caracterele ereditare, transmise intergeneraţional, sînt controlate exclusiv de gene; 2) genele pot suferi mutații; 3) mutațiile genetice nu sînt „direcționate” de organism ori de mediu, ci sînt cauzate aleatoriu, de „accidentul” pe care îl reprezintă evenimentul ce provoacă mutaţia; 4) mutațiile accidentale (întîmplătoare) modifică caracteristicile generației următoare; 5) generația următoare astfel modificată este fie favorizată de selecția naturală și devine un element important în continuarea populației, fie moare și iese din scenă. În felul acesta, măruntele modificări accidentale de la nivelul genelor fac ca o specie să alunece gradual înspre o alta, ce o înlocuiește pe prima și care este mai potrivită (adaptată) să supraviețuiască în noul mediu. Nimic nu este preadaptat, predeterminat, programat, dar nici nu este haotic; nimic nu se orientează către un scop, ci doar este direcționat pe etape, în funcție de răspunsurile structurilor funcționale la stimuli și la procesele adaptativ-evolutive, în funcție de posibilitățile astfel deschise - și ele urmate și în funcție de cea mai eficientă, în acel moment (din punctul de vedere al stării și dinamicii organismului, în mediul său concret).

cum să fie altcumva, dovezile vor apărea atunci cînd nivelul de cunoaștere al științei va ajunge la ele.

${ }^{36}$ În zilele noastre, așa-numitul efect Baldwin este tot mai des folosit ca punct de plecare și ca argument nu doar de către 
Întemeindu-se pe aceste postulate, SEM protejează ideea că selecția naturală constituie factorul și mecanismul crucial al evoluției viului (chiar dacă mai există și alți factori, aceștia nu pot fi decît subordonați și mai ales de slabă semnificație în comparație cu selecția naturală, care controlează orice interacțiune dintre factori) și că, în consecință, poate explica singură existența și forma oricărui organism care a trăit vreodată. Pusă în fața banalei observații că speciile sînt totuși distincte unele de altele, că par a nu urma legea unei modificări continue, graduale, în timp a organismelor, prejudecata-care nutrea un confortabil și măgulitor consens asupra mecanismelor evolutive-a aplicat aceeași soluție monodirecțională la chestiunea speciației, desăvîrșind astfel imaginea de forță şi de autoritate a sintezei pentru următoarea jumătate de secol $^{37}$.

Mișcarea pecetluitoare ${ }^{38}$ i-a aparținut lui Ernst Mayr (în Systematics and the Origin of Species, 1942, și Animal Species and Evolution, 1963), a cărui explicație privind emergența unei specii constă în apariția de mutații genetice întîmplătoare la un grup de organisme, în condiții de izolare geografică față de populația inițială, mutații care, de la un punct încolo, fac imposibilă împerecherea dintre indivizii grupului izolat (și mutant) și indivizii populației originare, chiar dacă izolarea geografică este anulată (continuă să existe deci, în această situație, izolarea temporală între specia creată și specia-mamă). Cea mai mică circumstanță izolantă declanșează procesul gradual și continuu al speciației, plasînd grupurile de organisme pe niveluri ce pot fi descrise concomitent sub raportul acumulării de variație (Mayr vorbește despre „stadii de speciație") și al solidităţii barierei dintre ele: populații propriu-zise, cu bariere slabe despărțitoare și încă transgresabile; subspecii, cu bariere mai clar ridicate; în sfîrșit, specii, separate de bariere puternice și complexe. Speciația înseamnă, așadar-folosind termenii lui Mayr-, diversificare, radialitate adaptativă și progres evolutiv substanțial, iar unitatea de evoluție nu mai este individul (ca în concepția lui Darwin), ci specia (populația), procesul desfășurîndu-se pe seama schimbării frecvenței genelor (alelelor) din bazinul genetic al speciei.

În deceniile care au urmat a devenit din ce în ce mai evident că ecuația geneticii cantitative nu rezolva problema evoluției morfologiei organismelor, nefiind nici suficientă, nici incluzivă. Trebuie, de altfel, să precizăm că Mayr însuși a intuit ceva din precaritatea viziunii sale, cînd a formulat singur ori a preluat de la oponenți două posibile obiecții: există un număr considerabil de specii fără variații geografice notabile (specii monotipice); există în natură numeroase cazuri ce nu își găsesc un loc comod în propusa schemă a speciației geografice.

Dar obiectivitatea științifică a biologului germano-american se diminuează drastic aici, căci acestora Mayr le-a răspuns, pe de o parte (în chestiunea primei obiecții), prin enumerarea unei serii de prezumții cărora le ignoră perfecta posibilitate de a fi formulate cu semn schimbat ori de a fi anulate de cercetări

neolamarckieni, dar și de către darwiniștii autentici și de alte categorii de evoluționiști.

${ }^{37}$ Avînd în vedere că singurul țel care îi unea pe adepții SEM se referea la eradicarea oricărei urme de lamarckism—și, implicit, de darwinism autentic-, feluritele variante pe care le-au prezentat aceștia era necoincidente sub alte aspecte decît cel al anti-lamarckismului și anti-darwinismului. De aceea, în afară de trecerea la index a celor două idei lamarckiene de forțătransmiterea trăsăturilor dobîndite și tendințele interne ale organismului, care explicau ceea ce Darwin nu reușise (mecanismul ereditar și apariția direcțiilor evolutive)—, din discursul acestora dispar cu desăvîrșire suprapopulația și lupta pentru existență, apărînd factori a căror existență și influență nu fuseseră negate de către Darwin, dar cărora le acordase un rol mărunt și adiacent (incomparabil mai mic decît cel pe care îl acordase factorilor lamarckieni): mutațiile, mărimea populației și structura ei, fluctuația numărului de indivizi in populație, durata generațiilor și rata succesiunii lor, locul speciei in ecosistem, migrațiile, longevitatea, cooperarea intraspecifică, influența mediului, izolarea reproductivă, hibridizarea, recombinarea genetică și, desigur, selecția naturală.

${ }^{38}$ Lucrurile par astfel din perspectiva contemporanilor tîrzii ai lui Mayr, care, pentru a se instrui, au profitat, la sfîrșitul secolului XX, de proximitatea omului și a cărților sale, și nu au făcut—cu unele excepții-drumul înapoi, pînă la predecesorii mai puțin longevivi ai acestuia, ori chiar pînă la Darwin însuși, pentru a găsi acolo ipotezele originale, negrevate încă de jargonul adesea prețios și artificial cu care operează Mayr. Pentru apariția și preluarea conceptului de 'breșă adaptativă (engl. key innovation, key adaptation sau adaptive breakthrough) — concept-cheie în teoriile despre emergența noilor specii (v. infra, în text), v. Darwin (care nu a folosit totuși termenul); apoi A.H. Miller (1949). Some ecological and morphological considerations in the evolution of higher taxonomic categories, în E. Mayr \& E. Schuzs (eds), Ornithologie als Biologische Wissenschaft, Carl Winter, Heidelberg, p. 84-88; G.G. Simpson (1953). The Major Features of Evolution, Columbia University Press, New York; G.G. Simpson (1959). The nature and origin of supra specific taxa, în „Cold Spring Harbor Symposia on Quantitative Biology”, 24, 
ulterioare: poate că studiile nu sînt suficiente, poate că habitatul este uniform totuși, poate că este vorba de o stagnare evolutivă, poate că avem de-a face cu o expansiune recentă a unei populații pînă de curînd riguros localizată etc. Pe de altă parte (în chestiunea celei de-a doua obiecții), prin reiterarea propriei poziții, întărind schema și forțînd cazurile să se potrivească acestei scheme prefabricate: în ciuda a ceea ce etalează natura, este totuşi posibil să luăm toate speciile dintr-un grup sistematic (păsări ori fluturi, e.g.), dintr-o regiune oarecare, și să le clasificăm potrivit stadiului de speciaţie căruia îi aparțin.

Ipoteza de lucru a lui Ernst Mayr devine în acest moment dogmă, căci cercetătorul concediază rapid ipoteze alternative și-și concentrează energia asupra identificării de fapte ce-i sprijină sau îi ilustrează ideea. Eleganța soluției și simplitatea explicației ${ }^{39}$ —în fapt, încîntarea și admirația estetică, așadar — țin loc de adevărul însuși și de strădania reală de ajunge la el, în ciuda faptului că oricînd și oriunde în lumea occidentală, după mijlocul secolului XX voci firave s-au opus curentului dominant, arătînd astfel că problema evoluției era încă departe de a fi rezolvată.

$\mathrm{Nu}$ toate aceste voci au putut oferi și alternative consistente şi coerente neodarwinismului; dar negăsirea rezolvărilor nu anulează realitatea problemei, astfel încît, pentru cine a știut să privească, a devenit clar că explicațiile cauzale mecaniciste, întemeiate exclusiv pe observațiile lui Mendel nu puteau da seama de starea și de dinamica realității biologice. Iar atunci s-a încercat a se face pasul înainte prin deschiderea unei uşi înspre trecut, înspre viziunea hulitului Lamarck.

O nouă teorie integratoare trebuia să poată explica deopotrivă evenimentele macroevolutive și microevolutive. Pentru aceasta, cercetătorii au introdus în discuţie descoperirile a trei arii ale biologiei, marginalizate de către SEM: embriologia, macroevoluția și omologia, privind mai îndeaproape ipoteze formulate în urma reinterpretării datelor fosile. Erau formulate idei ca acestea: rezolvarea problemelor macroevoluției nu mai poate fi lăsată în seama geneticii populațiilor; în schimb, acțiunile evolutive ale genelor implicate în creșterea și specificarea celulară trebuie considerate cruciale în formarea ordinelor animaliere superioare; genetica evolutivă pune în lumină procese evolutive omoloage la nivel embrionar, ce acționează în regiuni discrete, morfogenetice; aceste arii (care exemplifică natura modulară a dezvoltării embrionilor) par a face legătura dintre genotip și fenotip; așa cum celula (iar nu genomul ei) funcționează ca unitate a structurii organice și a funcției, tot astfel, cîmpul morfogenetic (iar nu genele ori celulele) trebuie considerat unitatea majoră a ontogeniei, ale cărei modificări determină modificări în evoluție; etc.

Așa se face că, sub presiunea a ceea ce putea fi observat și a ceea ce putea fi dedus în urma evaluării logice a evidențelor, cîțiva dintre chiar inițiatorii și întemeietorii SEM și biologi care se formaseră pe parcurs, ca C.H. Waddington, Ivan I. Schmalhausen, R. Riedl, M. Pigliucci, E. Koonin, S.J. Gould, N. Eldredge, au găsit oportun să dezvolte o nouă paradigmă explicativă. Numele prin care avea să fie cunoscută—Sinteza Evoluționistă Extinsă (SEE) - indică, antagonic, atît ambiția promotorilor ei de a produce explicații acolo unde sinteza clasică eșuase, cît și incapacitatea lor de a abandona totuși tiparul de gîndire neodarwinist ce șubrezise timp de aproape un secol șansele înţelegerii realităţii.

Un moment esențial în declanşarea acestei reforme ideologice l-a constituit activitatea experimentală a biologului Conrad H. Waddington, din 1942 și 1953, asupra embrionilor de Drosophila, în urma cărora a constatat apariția unor fenotipuri noi-așadar, ne-înnăscute—în condiții de mediu neobișnuite și

p. 255-271; în sfîrșit, E. Mayr (1954). Change of genetic environment and evolution, în J. Huxley, A.C. Hardy \& E. B. Ford (eds), Evolution as a Process, George Allen \& Unwin Ltd., London, p. 157-80 și E. Mayr (1960). The emergence of evolutionary novelties, în S. Tax (ed.), Evolution after Darwin, 1. The Evolution of Life. Its Origin, History, and Future, University of Chicago Press, p. 349-380.

${ }^{39}$ Reproducem un fragment din Systematics and the Origin of Species, 1942, a lui Mayr, pentru că ni se pare simptomatic pentru o stare de fapt în care cunoașterea ajunge să stagneze (ori chiar să fie ținută captivă într-o iluzie a ei înseși), născută din autosatisfacția pe care o poate încerca un cercetător (vorbim nu de altul decît de cel valoros) contemplîndu-și munca: „Acceptarea conceptului de specie biologică modernă, întemeiat pe principiul înlocuirii geografice, a avut ca rezultat o extraordinară simplificare a sistemului în toate grupurile în care a fost aplicat constant" (ed. Harvard University Press, 1999, p. 146, trad.n., F.G. \& A.C.). În orice izbîndă a spiritului și inteligenței umane, rafinarea și simplificarea sînt procese tîrzii, condiționate de existența unei soluții reale și comprehensive la o problemă oarecare; ele sînt futile, deci inutil de a fi aduse în discuție, dacă rezolvarea propusă eșuează ori nu ține seama de nuanțe și de elemente ce se comportă centrifug, ori nu reprezintă o noutate 
stresante $^{40}$. Deoarece fenotipurile au reapărut și în generațiile tîrzii, cînd embrionii din lineajul fenotipal nou nu au mai fost expuși ei înșiși mediului ostil, Waddington a concluzionat că trăsătura care definea fenotipul nou apărut (e.g., lipsa nervurilor de legătură în aripile musculițelor de oțet) fusese aproape complet asimilată genetic: ceea ce fusese la început trăsătură dobîndită (apărută într-un mediu excepțional) a devenit trăsătură ereditară (manifestată într-un mediu normal, pe calea eredității non-ADN).

Aparența de lamarckist a lui Waddington este puternică în acest punct-chiar dacă el a dezavuat asocierea cu predecesorul său francez și a negat vreo asemănare între teoria sa și cea a lui Baldwin (deși rar se găsesc apropieri mai mari între patru generații decît cele dintre Lamarck, Darwin, Baldwin și Waddington) , iar alți adepți mai tîrzii ai viziunii neodarwiniste insistă că ceea ce observase Waddington (esența conceptului său, 'asimilare genetică, fiind aceea că un stimul de mediu oarecare scoate la iveală un caracter fenotipal ce se manifestă în generaţii succesive chir și în absența stimulului respectiv datorită expunerii variabilității genetice preexistente la acțiunea selecției...) nu reprezintă moștenire a trăsăturilor dobîndite, ci răspuns genotipal la stimuli de mediu.

De remarcat însă că cei care se grăbesc să-l smulgă pe Waddington din fie și firava îmbrățișare cu Lamarck par a omite faptul că naturalistul francez nu formulase o teorie care să fi beneficiat de descoperirile biologiei moleculare din secolul XX. Nici Darwin n-a făcut-o! Dar ei se comportă ca și cum singura încheiere posibilă a observațiilor și problemelor ridicate de Lamarck, a rezonărilor sale este imaginea evoluției cuprinsă în exemplele animaliere din Philosophie Zoologique!

O altă nouă sinteză. Ideile lui Waddington au contribuit la redeschiderea stigmatizatului caz al lui Lamarck (uneori tacit, mereu neobosit), ultima generaţie de cercetători-dispuși să iasă din limitările neodarwinismului ${ }^{41}$ - recunoscînd și luînd de la el esența.

Într-o serie de lucrări ${ }^{42}$ apărute mai ales după intrarea în secolul XXI, cercetători precum geneticiana israeliană Eva Jablonka și colaboratorii ei, apoi imunologul australian R.J. Steele (a cărui pălărie Dawkins încă nu a mîncat-o, după cum singur promisese) și echipa sa ${ }^{43}$, conturează o altă nouă sinteză, care atacă deopotrivă sinteza modernă și sinteza extinsă (practic, neodarwinismul ultimilor șaizeci de ani), punînd

decît sub raportul jargonului folosit.

${ }^{40}$ În experimentul din 1942 (v. art. Canalisation of development and the inheritance of acquired characters, în „Nature”, 150, p. 563-564), embrionii au fost expuși la vapori de eter, iar un număr considerabil de exemplare a prezentat ulterior un al doilea torace; al doilea studiu (v. art. Genetic assimilation of an acquired character, în „Evolution”, 7, p. 118-126) a presupus expunerea embrionilor la şocuri calorice, în urma cărora numeroase exemplare au prezentat aripi cu nervuri modificate (fără nervuri de legătură; în engl. cross-veinless) faţă de fenotipul originar. Și în primul caz, și în al doilea, experimentele au fost repetate timp de mai multe generaţiii, împerechindu-se mereu exemplare din fenotipul nou, iar rezultatele au fost de fiecare dată aceleaşi, crescînd, în fapt, procentul fenotipului nou; în final, fenotipurile noi au continuat să apară și în condițiile în care nu s-a mai creat mediul neobișnuit și stresant care declanșase modificările.

${ }^{41}$ Se poate vorbi despre o ,reformă a neodarwinismului”, care poate fi însă un foarte bun neolamarckism. Progresul în această direcție este totuși la început, întrucît mirajul oferirii adevărului evoluției prin prismă neodarwinistă continuă să fie atît de seducător, încît nu sînt puțini aceia care, bucurîndu-se de privilegiul unei descoperiri oarecare—potențial revoluționare一, se simt datori să o subordoneze dogmei centrale, ajustînd, eventual, teoria la noul fapt revelat.

Obişnuința de a repudia orice referire la Lamarck produce efecte ridicole, cînd, constatîndu-se, pe de o parte legitimitatea chestionării cadrului îngust al sintezei moderne și a discutării serioase a supoziției despre transmiterea variațiilor induse de mediu, pe de altă parte se pune întrebarea dacă aceste vădite probleme nu s-ar putea rezolva... altfel, cumva fără a se pomeni de Lamarck...

${ }^{42} \mathrm{~V}$. , e.g., E. Jablonka (1994). Inheritance systems and the evolution of new levels of individuality, în „Journal of Theoretical Biology", 170, p. 301-309; idem (2002). Information: Its interpretation, its inheritance, and its sharing, în „Philosophy of Science”, 69, p. 578-605; idem (2004a). From replicators to heritably varying traits: The extended phenotype revisited, în „Biology and Philosophy”, 19, p. 353-375; idem (2004b). Epigenetic epidemiology, în „International Journal of Epidemiology”, 33, p. 929-935; E. Jablonka \& M.J. Lamb (1995). Epigenetic Inheritance and Evolution: The Lamarckian Dimension, Oxford University Press, Oxford; idem (2005). Evolution in Four Dimensions. Genetic, Epigenetic, Behavioral, and Symbolic Variation in the History of Life, Massachusetts Institute of Technology; idem (2008). Soft inheritance: challenging the modern synthesis, în „Genetics and Molecular Biology”, 31, nr. 2; E. Jablonka, M.J. Lamb \& E. Avital (1998). "Lamarckian” mechanisms in darwinian evolution, în „Trends in Ecology and Evolution”, 13, p. 206-210.

${ }^{43}$ Spre deosebire de cazul unor neodarwiniști ca R. Dawkins—ale cărui lucrări de popularizare și spectacole mediatice, în- 
în lumină, ca idee fundamentală, aşa numita transmitere slabă (engl. soft inheritence)—care postulează că variațiile care apar în timpul dezvoltării organismului și care sînt regulate pot fi transmise generației următoare. Aceasta nu anulează adevărul că selecția naturală are nevoie de variație fenotipală transmisibilă pentru a se putea realiza și că aceasta este oferită pe cale genetică. (Re)Afirmarea nu înseamnă însă și exclusivism: evidențiind situații ce scapă explicaţiei agreate de perspectiva întemeiată pe genă, cercetătorii lucizi ai acestei noi generații opun viziunii înguste a sintezelor precedente cîteva afirmații puternice: că ereditatea implică mai mult decît $\mathrm{ADN}$-ul; că variațiile fenotipice independente de variațiile din secvența ADN și modificările ADN orientate de sistemele de control epigenetice reprezintă o sursă importantă de variație ereditară; că, în consecință, ele pot contribui la schimbările evolutive; că unele variații ereditare nu sînt aleatorii; că, în anumite condiții, mecanismele care stau la baza transmiterii epigenetice pot conduce la schimbări saltatorii care duc la reorganizarea epigenomului; că, date fiind caracterul simbiotic al existenței anumitor organisme (om și paraziții săi interni, de pildă) și trecerea simbionților de la o generație-gazdă la alta, ar putea fi benefic pentru știință să se ia în calcul posibilitatea ca unitatea de selecției să fie acest tip de comuniune; că macroevoluția poate fi rezultatul unor mecanisme specifice, generate de un mediu solicitant, care produc reorganizarea genomului, sau mutații sistemice; că, în sfîrşit, schimbarea evolutivă poate rezulta din instruire, ca și din selecție.

Așadar, natura exersează trei căi alternative-ignorate de înțelegerea neo-darwinistă—prin care obține variație fenotipală: calea epigenetică, ce se folosește de epimutații, mai exact, de modificări în structura cromatinică, ce influențează durabil stările expresiei genetice; calea comportamentală/culturală, ce are în vedere modalitățile prin care diverse comportamente (noi) ajung să se răspîndească în cadrul grupurilor de indivizi și, apoi, să fie transmise—dată fiind condiția manifestării lor efective, în prezența receptorilor-, persistînd astfel intergenerațional; și calea simbolică, ce se referă la formele elaborate de moștenire culturală, uneori latentă—precum informația stocată în genele neexprimate—, întemeiate pe gîndire simbolică şi manifestate în limbaj, artă, știință etc.

Aceste tipuri de evoluție—cuprinse într-o teorie mai complexă și mai convingătoare ${ }^{44}$ — depind unele de altele și interacționează multidirecțional, iar a le ierarhiza în privința importanței ar fi un demers absurd, din moment ce fiecare caz de evoluție poate fi unul aparte, iar cazurile în sine nu pot fi ierarhizate.

Și totuși, Lamarck. De peste 2000 de ani omenirea se educă și așteaptă cu încredere rezultate consecvente la intensitatea producerii acestui proces orientat și conștient. Adică ființa umană crede în educaţie, încredințată fiind că a aflat o lege a cauzalității, care îi permite să-și controleze acțiunile cu ajutorul științei pe care i-a dat-o experiența acumulată. Deși această credință nu ține seamă nici de faptul că omul nu este decît una dintre milioanele de specii vii-singura care a instituționalizat educaţia—, nici de faptul că explicaţia evoluționistă este universală și nu se referă doar la specia $H$. sapiens sapiens, dificultățile nu apar din această direcție. Ele se datorează neînțelegerii a două realități puternice: a) amploarea și profunzimea rezultatelor educaţiei sînt sever limitate de factori infinit mai puternici (de mediu, genetici și rezultați din intersecția conjuncturală a factorilor sociali, mentalitari și comportamentali) şi b) concomitent cu funcționarea și cu generarea de produse, procesul evolutiv se reconfigurează structural-funcțional, cunoaște adaptări și acumulări, generînd mereu produse tot mai complexe și autodepăşindu-se continuu.

Explicația lui Lamarck conținea elemente ce puteau servi la tot felul de deducții (nu neapărat coincidente cu ideile savantului francez) care reliefau factorii volitiv, vitalist sau finalist. Cea a lui Darwin-cu toate că nu susținea că lumea vie funcționează în modalități stohastice, fiind condusă de pura întîmplareconținea elemente ce puteau permite să fie deturnată în acest sens și transformată în suport al atotputerniciei selecției naturale aleatorii, devenind astfel un simbol egalitarist. Aceasta a fost „întîmplarea” care a

cărcate de umoristic aplomb și grevate de moștenita trăsătură dobîndită a amestecului weismannian de fermitate și dispreț, au ademenit mai multe suflete decît mințile convinse de Originea speciilor —, teoria acestora lor se întemeiază pe cît posibil și absolut onorant pe observații și interpretări furnizate de minuțioase cercetări punctuale asupra a nenumărate specii de organisme și tipuri de mecanisme, prin care se încearcă stricta descriere a ceea ce Natura lasă a fi descoperit.

${ }^{44} \mathrm{Pe}$ alocuri tocmai datorită ezitărilor și rezervelor pe care le exprimă artizanii ei. 
făcut ca una să fie respinsă, iar alta selectată și supusă prelucrărilor.

Contextul general a fost dat de faptul că, mai ales după H. Spencer și pe fondul exagerării caracterului educabil al ființei umane, neodarwiniștii aveau nevoie de o justificare cu aparență științifică, prin care să respingă consecințele exagerate rezultînd din interpretarea abuzivă a explicaţiei lamarckiene și neolamarckiene, derivate din ideile transmiterii trăsăturilor dobîndite și acțiunii tendințelor interne. (De fapt, Lamarck și urmașii săi autentici nu susțineau perfectibilitatea ființei umane, în conformitate cu vreun principiu vital sau cu finalități voite și autopropuse, ci doar că direcția în care se transformă speciile este inerent adaptativă.) Pe de altă parte, deși ei considerau că întreaga civilizație stă pe fundamentul inflexibil și neconvertibil genetic, al selecției naturale, nu puteau nega pur și simplu ideea educației, dar o puteau alunga din zona genetică într-una nesupusă sever rigorilor fizico-chimice, adică în cea epigenetică și apoi în derivata comportamentală. Totodată, neputînd nega că anumite trăsături păreau a se transmite, neodarwiniștii celei de-a doua jumătăți a secolului XX vor vorbi depre trăsăturile epigenetice ca despre niște forme „slabe” de ereditate, expediindu-le într-un apendice al biologiei. Toate acestea au avut consecințe pentru știință și pentru morala, legislația și mentalitatea socială.

Dincolo de esența celor susținute de către Lamarck, acesta vede devenirea universală și ajunge la o idee care abia în ultimii cincizeci de ani a ajuns a începe să fie cercetată și înțeleasă deductiv, și anume că viaţa nu este un dat, ci un proces dezvoltat prin exercițiu adaptativ și că însăși evoluția evoluează. Adică viul apare în consecința devenirii neviului, iar evoluția, o dată amorsată, poate duce nu doar la devenirea organismelor, ci și la aceea a mecanismului evolutiv. Iar toate acestea nu se petrec nici aleatoriu, nici programat, nici conform unei voințe, nici conform unei finalități. Ele se petrec în virtutea acțiunii acelorași legi care pun elementele în interacțiune, generînd combinații inexistente anterior, structuri și funcții adaptate, mereu mai complexe și dotate astfel cu capacități de a evolua ca urmare a stocării și transmiterii informației existente și achiziţionate. Este un proces coerent, nu un șir incoerent de întîmplări fericite validate statistic.

Darwin observă și explică dezvoltări în fond restrînse ca amploare și profunzime, dintr-o perspectivă care bănuiește complexitatea, dar pe care o scapă, adesea alăturînd sincronii, dar fără a ajunge la continuumul diacronic.

La rîndul său, sub toate formele pe care le cunoaște, neodarwinismul constituie o decădere a darwinismului întrucît are o atributele unei religii, în vreme ce lamarckism-darwinismul le avea pe cele ale unei științe. De aceea, precum o religie, neodarwinismul este o filozofie local-regională, valabilă pentru un grup constituit cumva, pe anumite criterii, și care tinde să se impună tuturor mai degrabă forțat, în vreme ce explicațiile lamarckiană și autentic darwinistă, în veritabil spirit științific, au caracter universal, fiind adevărate indiferent de starea, năzuințele și temerile vreunui grup.

După ce, oarecum prometeic, Lamarck și Darwin arătaseră că ființa umană deține capacităţi ce ar putea dezvolta atribute tot mai complexe și mai adaptate, weismannismul, oarecum tartuffian, îl redă pe om Divinității, de data aceasta uneia pe deplin camullate și oricînd convertibile în orice altceva. Deși weismannismul și derivatele sale arată cu ostentaţie că poartă straiele științei, comportamentul care răzbate cu tărie este cel al unei religii exclusiviste, întemeiate pe o dogmă intangibilă, care demonizează orice neaderent și sanctifică orice adept înfocat, în cele din urmă devorînd totul. 